\title{
Persistent Receptor Activity Underlies Group I mGluR-Mediated Cellular Plasticity in CA3 Neuron
}

\author{
Steven R. Young, ${ }^{1,2}$ Shih-Chieh Chuang, ${ }^{1,2}$ Wangfa Zhao, ${ }^{1,2}$ Robert K. S. Wong, ${ }^{1,2,3 *}$ and Riccardo Bianchi ${ }^{1,2 *}$ \\ ${ }^{1}$ The Robert F. Furchgott Center for Neural and Behavioral Science, Department of Physiology and Pharmacology, ${ }^{2}$ School of Graduate Studies Neural and \\ Behavioral Science Program, and ${ }^{3}$ Department of Neurology, State University of New York Downstate Medical Center, Brooklyn, New York 11203
}

Plastic changes in cortical activities induced by group I metabotropic glutamate receptor (mGluR) stimulation include epileptogenesis, expressed in vitro as the conversion of normal neuronal activity to persistent, prolonged synchronized (ictal) discharges. At present, the mechanism that maintains group I mGluR-induced plasticity is not known. We examined this issue using hippocampal slices from guinea pigs and mice. Agonist [(S)-3,5-dihydroxyphenylglycine (DHPG), 30-50 $\mu \mathrm{M})$ ] stimulation of group I mGluRs induces persistent prolonged synchronized (ictal-like) discharges in CA3 that are associated with three identified excitatory cellular responses-suppression of spike afterhyperpolarizations, activation of a voltage-dependent cationic current, and increase in neuronal input resistance. Persistent prolonged synchronized discharges and the underlying excitatory cellular responses maintained following induction were reversibly blocked by mGluR1 antagonists [(S)-+- $\alpha$-amino-4-carboxy-2-methylbenzeneacetic acid (LY 367385), 50, 100 $\mu \mathrm{M}$; CPCCOEt (hydroxyimino)cyclopropa[b]chromen-1a-carboxylate ethyl ester, $100 \mu \mathrm{M}$ ], and to a lesser extent by the mGluR5 antagonist MPEP [2-methyl-6-(phenylethynyl)pyridine hydrochloride, $50 \mu \mathrm{M}$ ]. Activation of persistent cellular responses to DHPG were unaffected by tetrodotoxin $(0.5-1 \mu \mathrm{M})$ or perfusion with low $\mathrm{Ca}^{2+}(0.2 \mathrm{~mm})-\mathrm{Mn}^{2+}(0.5 \mathrm{~mm})$ media-conditions that suppress endogenous glutamate release. The pharmacological profile of the blocking action of the group I mGluR antagonist MCPG [(RS)- $\alpha$-methyl-4carboxyphenylglycine, 50-500 $\mu \mathrm{M}$ ] on persistent cellular responses was different from that on cellular responses directly activated by DHPG. These data indicate that transient stimulation of group I mGluRs alters receptor properties, rendering them persistently active in the absence of applied agonist or endogenous glutamate activation. Persistent receptor activities, primarily involving mGluR1, maintain excitatory cellular responses and emergent prolonged synchronized discharges.

\section{Introduction}

Stimulation of group I metabotropic glutamate receptors (mGluRs) induces long-term modification of population behavior in CA3 neurons of the hippocampus. Synaptic (Chuang et al., 2005) or agonist (Merlin and Wong, 1997; Zhao et al., 2011) activation of group I mGluRs converts normal activity into intense periodic synchronized discharges. The discharges resemble ictal discharges in that the duration is prolonged (up to $15 \mathrm{~s}$ ) and that synchronized oscillations at beta frequency $(12-27 \mathrm{~Hz})$ are embedded within each discharge (Taylor et al., 1995; Merlin and Wong, 1997; Wong et al., 1999, 2002). The conversion of the discharge pattern elicited by $(S)$-3,5-dihydroxyphenylglycine (DHPG) is long lasting, persisting long after the removal of the inducing stimulus (Merlin and Wong, 1997; Bianchi et al., 2009).

\footnotetext{
Received July 12, 2012; revised Nov. 15, 2012; accepted Dec. 6, 2012.

Author contributions: S.R.Y., R.K.S.W., and R.B. designed research; S.R.Y., S.-C.C., and W.Z. performed research; S.R.Y., S.-C.C., W.Z., and R.B. analyzed data; S.R.Y., R.K.S.W., and R.B. wrote the paper.

This work was supported by the FRAXA Research Foundation and National Institutes of Health Grant NS35481. We thank Drs. James Celentano, Michaelangelo Fuortes, and Alejandro Salas for their assistance.

*R.K.S.W. and R.B. contributed equally to this work.

The authors declare no competing financial interests.

Correspondence should be addressed to either Riccardo Bianchi or Robert K. S. Wong, Department of Physiology and Pharmacology, Box 29, SUNY Downstate Medical Center, 450 Clarkson Avenue, Brooklyn, NY 11203. E-mail: rbianchi@downstate.edu or bwong@downstate.edu.

DOI:10.1523/JNEUROSCI.3338-12.2013

Copyright $\odot 2013$ the authors $\quad 0270-6474 / 13 / 332526-15 \$ 15.00 / 0$
}

Recent data indicate that the induction of persistent prolonged synchronized discharges via group I mGluR stimulation may underlie epileptogenesis encountered in fragile X syndrome (Bear et al., 2004; Chuang et al., 2005; McNamara et al., 2006; Dölen et al., 2007).

Group I mGluR-elicited prolonged synchronized discharges are driven, at the single-cell level, by a concatenation of excitatory effects including suppression of afterhyperpolarizations (AHPs) (Young et al., 2004; Pan et al., 2010), increased cell input resistance $\left(\mathrm{R}_{\mathrm{in}}\right)$ (Bianchi et al., 1999; Chuang et al., 2001), and induction of a voltage-dependent cationic current, $I_{\mathrm{mGluR}(\mathrm{V})}$ (Chuang et al., 2000, 2001). Like prolonged synchronized discharges, these intrinsic cellular properties are plastic_-once established by transient group I mGluR agonist stimulation, persistent AHP suppression (Young et al., 2008) and $I_{\mathrm{mGluR}(\mathrm{V})}$ generation last for hours after agonist washout (Bianchi et al., 2009).

A noted property of persistent group I mGluR-induced prolonged synchronized discharges - whether induced by agonist (Merlin and Wong, 1997) or synaptic (Chuang et al., 2005) stimulation - is that they are reversibly suppressed by group I mGluR antagonists. Reversible block by group I mGluR antagonists is also observed for another form of persistent changes elicited by DHPG. Group I mGluR stimulation induces long-term synaptic depression (LTD) in CA1 (Palmer et al., 1997; Huber et al., 2000; Huang and Hsu, 2006). Application of group I mGluR antagonists during the maintenance phase of LTD restored synaptic amplitude to control levels via reinsertion of internalized AMPA 
receptors into the cell membrane (Huang and Hsu, 2006). These studies raise the possibility that maintained plastic responses induced by group I mGluR stimulation are sustained by persistent activity of the receptors themselves. Accordingly, we propose that transient group I mGluR stimulation can produce a long-term alteration of receptor function, enabling a persistent activation of group I mGluRs, thereby eliciting long-term responses that outlast agonist washout.

Persistent receptor activity might result either from a maintained elevated concentration of agonist or from an alteration of receptor properties. We evaluate these possibilities by studying the plastic cellular underpinnings of prolonged synchronized discharges - persistent AHP suppression, $\mathrm{R}_{\text {in }}$ increase, and $I_{\text {mGluR(V) }}$ generation. We show that persistent group I mGluR activity is not caused by elevated levels of agonist. Instead, group I mGluR stimulation alters receptor properties to maintain long-lasting cellular responses and epileptiform discharges.

\section{Materials and Methods}

Slice preparation. A total of 89 guinea pigs and 15 mice, all males, were used in these experiments. Fmr1 ${ }^{-1-}$ slices were prepared from $6 \mathrm{Fmr} 1$ knock-out mice (Zhao et al., 2011). Animal use procedures were in accord with guidelines of the Institutional Animal Care and Use Committee of the State University of New York Downstate Medical Center (protocol number 05-194-10). Hippocampal slices 300-400 $\mu \mathrm{m}$ thick were cut as described previously (Bianchi and Wong, 1995). In brief, young adult guinea pigs and mice were anesthetized with halothane and decapitated. Hippocampi were removed, and transverse slices were cut in ice-cold artificial CSF (aCSF; see below) using a vibratome (Vibratome). For current-clamp experiments, slices were stored at $32^{\circ} \mathrm{C}$ for $0.5-1 \mathrm{~h}$ in $\mathrm{aCSF}$ and then at room temperature for $\geq 0.5 \mathrm{~h}$ before use. Slices were then submerged in a recording chamber at $30-31^{\circ} \mathrm{C}$ (volume, $<1 \mathrm{ml}$ ) and superfused with aCSF at $3-5 \mathrm{ml} / \mathrm{min}$. A platinum ring with attached nylon threads was used to hold slices against the bottom of the recording chamber. This prevented the slice from moving but allowed solution exchange at the bottom of the slice. Artificial CSF consisted of (in mM) $124.0 \mathrm{NaCl}, 26.0 \mathrm{NaHCO}_{3}, 5.0 \mathrm{KCl}, 1.6 \mathrm{MgCl}_{2}, 2.0 \mathrm{CaCl}_{2}$, and 10.0 D-glucose, and was held at pH 7.4 by bubbling with $95 \% \mathrm{O}_{2}, 5 \% \mathrm{CO}_{2}$. Low $\mathrm{Ca}^{2+} / \mathrm{Mn}^{2+}$ solution had the same composition except that $\mathrm{CaCl}_{2}$ was reduced to $0.2 \mathrm{~mm}$ and $0.5 \mathrm{~mm} \mathrm{MnCl}_{2}$ was added. The recording chamber was placed in a magnetic stainless steel plate attached to the mechanical stage of an inverted microscope (Diaphot; Nikon). The necessary micromanipulators were attached to the same plate. Electrode placements were made using a Nikon dissecting scope.

Electrophysiology. Electrophysiological recording techniques were conventional and have been described previously (Bianchi et al., 1999; Chuang et al., 2001). Current-clamp recordings were made with micropipettes pulled from thin-walled glass capillaries (TW 100F; World Precision Instruments) and filled with $2 \mathrm{~m}$ potassium acetate (typical resistances, 30-50 M $\Omega$ ). Recordings were made from CA3 pyramidal cells using an Axoclamp 2B amplifier (Molecular Devices). An oscilloscope (DSO 400; Gould Instrument Systems) and chart recorder (TA240; Gould Instrument Systems) were used for immediate display of voltage and current signals. These signals were also low-pass filtered (eight-pole Bessel, $-3 \mathrm{~dB}$ at $1 \mathrm{kHz}$ ) and sampled at $5 \mathrm{kHz}$ for storage and later computer analysis (pCLAMP, TL-1; Molecular Devices). Cells were maintained at a hyperpolarized membrane potential $\left(V_{\mathrm{m}} ; \approx-67 \mathrm{mV}\right.$; Young et al., 2008) to decrease spontaneous firing following application of group I mGluR agonist, and to minimize the appearance of a voltagedependent group I mGluR-induced afterdepolarization (Young et al., 2004). The medium AHP (mAHP) was elicited by single action potentials triggered by $4 \mathrm{~ms}$ square current pulses $(+0.2$ to $+2.5 \mathrm{nA})$. The slow AHP (sAHP) followed either a $100 \mathrm{~ms}$ square current pulse $(+0.2$ to $+2.5 \mathrm{nA})$ or a train of four brief current pulses $(4 \mathrm{~ms} ;+0.2$ to $+2.5 \mathrm{nA})$. Cell $\mathrm{R}_{\mathrm{in}}$ was monitored throughout the experiment using hyperpolarizing current pulses ( $150 \mathrm{~ms} ;-0.1$ to $-0.5 \mathrm{nA}$ ).

Voltage-clamp experiments were performed on slices in an interface chamber at $34-36^{\circ} \mathrm{C}$, as previously described (Chuang et al., 2001), using the discontinuous single electrode voltage-clamp mode of an Axoclamp 2A amplifier (Molecular Devices). Slices were allowed to recover from the isolation procedure for $1 \mathrm{~h}$ in the interface chamber before use. Electrodes were pulled from thin-walled glass tubing with filament (WPI) and had resistances of $30-70 \mathrm{M} \Omega$ when filled with $2 \mathrm{M}$ potassium acetate. The headstage output was monitored continuously on an oscilloscope, and the switching frequency $(4-6 \mathrm{kHz})$ and gain $(0.5-1 \mathrm{nA} / \mathrm{mV})$ were adjusted so that the decay of voltage transients was complete between switch cycles. Voltage and current signals were digitized and stored in an Intel Pentium-based computer using a Digidata 1322A analog to digital converter controlled by pClamp software (Molecular Devices). $I_{\mathrm{mGluR}(\mathrm{V})}$ tail currents were obtained by subtracting the control response to a depolarizing voltage step from -125 to $-45 \mathrm{mV}$ from the current response to the same step after treatment with DHPG. $I_{\text {mGluR(v) }}$ was measured at the end of the step, and currents under different conditions were compared using ANOVA.

Pharmacological agents. Unless noted, all control solutions contained 6-cyano-7-nitroquinoxaline-2,3-dione (CNQX; $10 \mu \mathrm{M})$ and 3-((R,S)-2carboxypiperazin-4-yl)-propyl-1-phosphonic acid (CPP; $20 \mu \mathrm{M})$ in aCSF to block the ionotropic glutamate receptors (iGluRs)—AMPA and NMDA receptors, respectively. The group I mGluR-specific agonist DHPG (30-50 $\mu \mathrm{M})$ was applied by addition to the bath. DHPG applied for $30 \mathrm{~min}$ led to long-lasting AHP suppression, while applications for $<5$ min produced readily reversible effects (Young et al., 2008). To induce long-lasting responses, DHPG was applied for at least $30 \mathrm{~min}$. Group I mGluRs were blocked using either $(S)-+-\alpha$-amino-4-carboxy-2-methylbenzeneacetic acid (LY 367385; $100 \mu \mathrm{M}$ ) plus 2-methyl-6-(phenylethynyl)pyridine hydrochloride (MPEP; $50 \mu \mathrm{M}$ ) or (RS)- $\alpha$-methyl-4-carboxyphenylglycine (MCPG). LY 367385 (50 or $100 \mu \mathrm{M}$ ) or 7-(hydroxyimino)cyclopropa[b] chromen-1a-carboxylate ethyl ester (CPCCOEt; $100 \mu \mathrm{M}$ ) and MPEP (50 $\mu \mathrm{M})$ were also used for selective block of mGluR1 and mGluR5, respectively. Tetrodotoxin (TTX; $0.5-1 \mu \mathrm{M}$ ) was used to block $\mathrm{Na}^{+}$action potentials. DHPG, LY 367385, MPEP, MCPG, and CPCCOEt were purchased from Tocris Bioscience. All other chemicals were from Sigma-Aldrich.

Measurements and statistical analysis. The duration of an individual synchronized discharge was measured from the beginning of the first action potential to the repolarization of the last action potential of the burst. All AHP measurements were made in the presence of CNQX and CPP or TTX. Medium AHPs were stimulated by single action potentials and were measured as the difference between baseline membrane potential and membrane potential $150 \mathrm{~ms}$ after the spike. Slow AHPs were triggered either by $100 \mathrm{~ms}$ depolarizing pulses or by trains of four action potentials. They were measured by subtracting the baseline from the minimum membrane voltage between 200 and 700 ms postspike (see Fig. $2 \mathrm{Ca}$ ) (Young et al., 2008). Measuring AHPs in this way did not eliminate temporal overlap between the potentials. However, the different time courses of mAHPs and sAHPs (mAHP half-width $=185 \pm 53 \mathrm{~ms}$; sAHP peak at $299 \pm 21 \mathrm{~ms}$ postspike) (Young et al., 2008) enabled temporal separation of the bulk of the potentials. More important was that AHPs, following single action potentials with minimal contribution of sAHP, were used to measure peak mAHP, whereas multiple action potentials were elicited to selectively augment sAHPs over mAHPs for sAHP measurements (Young et al., 2004, 2008). In voltage-clamp experiments, the AHP current $\left(I_{\mathrm{AHP}}\right)$ amplitude was measured at the position of the peak of the control response (100-500 ms postspike) (see Fig. $7 B$ ). Control AHP amplitude was usually the amplitude of the AHP before application of DHPG. For purposes of comparison, AHP amplitudes in Figures 3, $B$ and $C$, and 5 were expressed as a percentage of the control amplitude for each cell. In Figure 4, where the effects of MCPG on persistently suppressed AHPs were measured repeatedly over a period of several hours, control measurements of AHP size were made during drug washout periods between each application of MCPG. This eliminated any influence of gradual recovery of sAHP amplitude occurring over the several hours of the experiment. Afterdepolarizations that had not decayed to baseline by the time of measurement were recorded as negative percents. Averaged values from different cells are reported as mean \pm SEM. Comparisons of drug effects were made using ANOVA and are reported as $p$ values.

The dose-response curves in Figure 4 were fit by Hill equations (see below) using nonlinear regression (Prism; GraphPad Software). Com- 
A

a

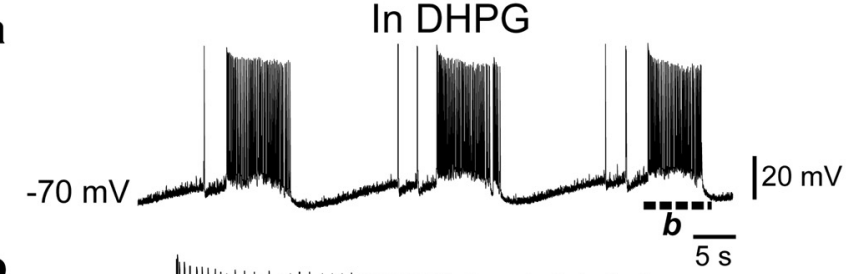

b

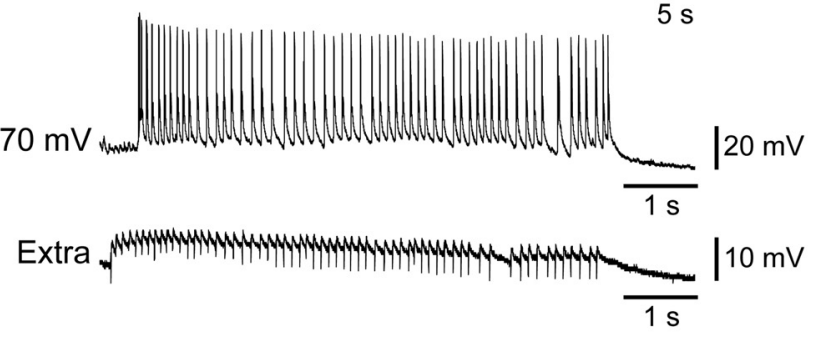

B

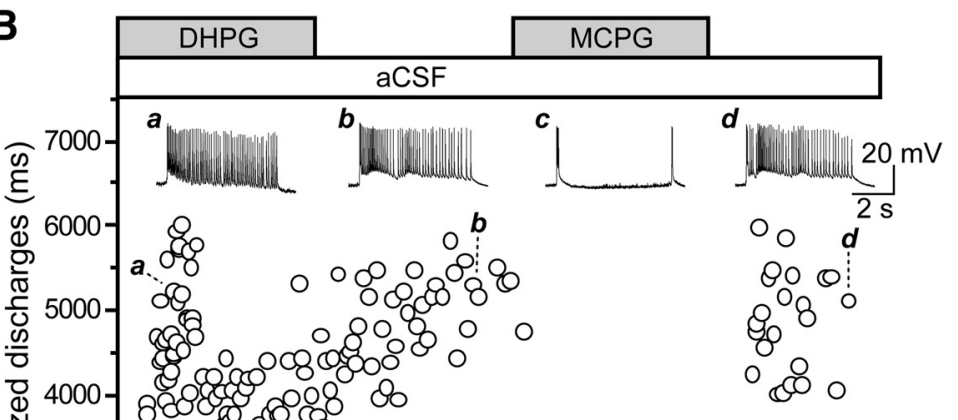

$\mathrm{O}$

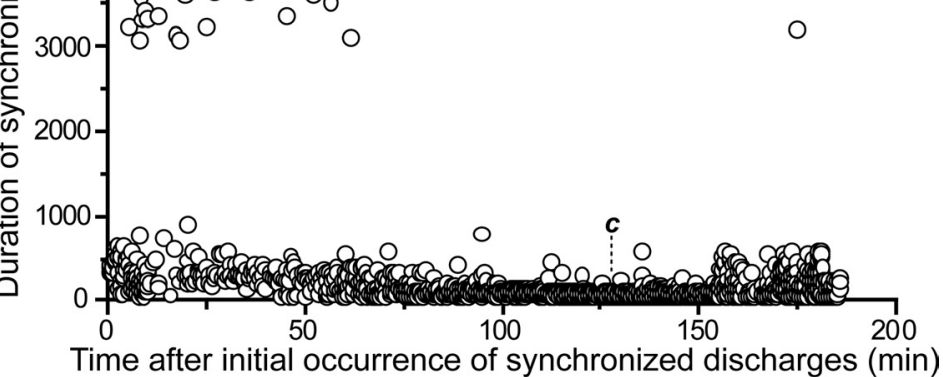

C

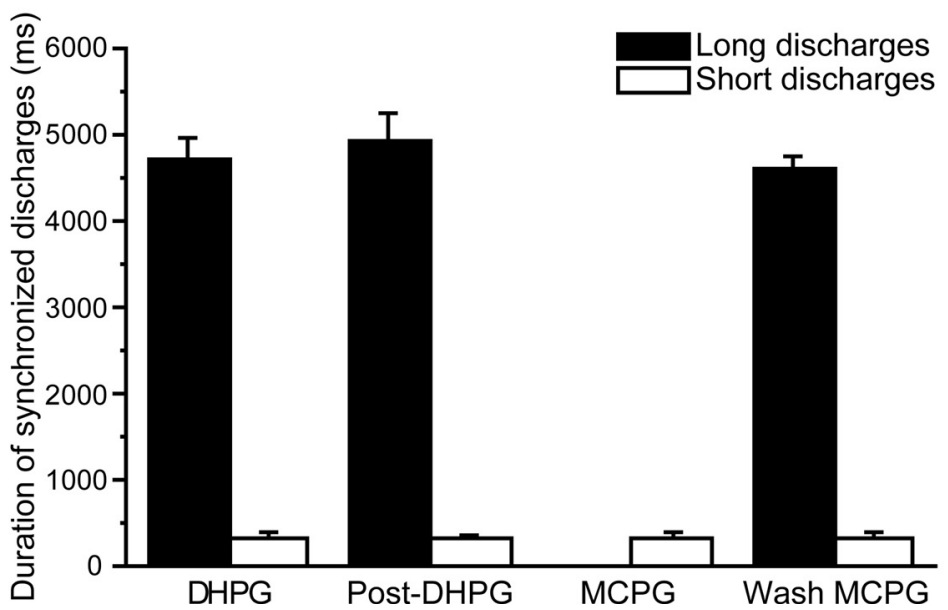

Figure 1. Group I mGluR-induced epileptiform bursting is temporarily reversed by a group I mGluR antagonist. Aa, In hippocampal slices perfused with aCSF, exposure to the group I mGluR agonist DHPG induces CA3 cells to fire in rhythmic epileptiform discharges. The discharge indicated by a dashed line in $\boldsymbol{A} \boldsymbol{a}$ is shown at a faster time scale in $\boldsymbol{A} \boldsymbol{b}$. Intracellular $(\boldsymbol{A a}, \boldsymbol{A} \boldsymbol{b})$ and extracellular $(\boldsymbol{A} \boldsymbol{c})$ recordings indicate that these epileptiform discharges resemble ictal epileptic seizure discharges (Musumeci et al., 1999; Sabaratnam et al., 2001; D'Ambrosio et al., 2009) in that (1) the entire hippocampal neuronal population is recruited to participate in hypersynchronous discharges, which last 2-15 s each occurring at intervals of $10-20 \mathrm{~s}$; and (2) within each discharge, synchronized oscillations of the population occur at beta-frequency range with a mean frequency of $\sim 15 \mathrm{~Hz}$ (Taylor et al., 1995; Merlin and Wong, 1997; Wong et al., 2002). Within each discharge (Ab, Ac), firing frequency slows from typically 27 to $8-12$ parison of the dataset showing the blocking effect of MCPG on AHP suppression in the presence of DHPG to the data showing block of persistent AHP suppression after washout of DHPG was done in two steps. In the first step, the entire curves were compared using an $F$ test. The two datasets were fit separately by three-parameter Hill equations $[Y=\mathrm{Top} /(1+$ $\left(\mathrm{EC}_{50} / X\right)^{\wedge}$ Hill Slope $\left.)\right]$. The data were then combined and fit by the same equation. The significance of the improvement of the fit to the separate datasets versus the combined set was evaluated using the $F$ ratio (14.94) (Motulsky and Ransnas, 1987) converted to a $p$ value $\left(7.15 \times 10^{-6}\right)$, which indicated that the data were significantly better fit separately than when combined. Having shown in this way that the two dose-response curves were different, in the second step we fit each set of data with two different equations (Prism), a threeparameter Hill equation $\left(Y=\mathrm{Top} /\left(1+\left(\mathrm{EC}_{50} /\right.\right.\right.$ $X)^{\wedge}$ Hill Slope) or a four-parameter Hill equation $(Y=$ Bottom $+($ Top - Bottom $) /$ $\left(1+\left(\mathrm{EC}_{50} / X\right)^{\wedge}\right.$ Hill Slope $)$, and used an $F$ test (Prism) to calculate a $p$ value for the improvement of fit to the four-parameter over the three-parameter models. A $p$ value of $<0.05$ (0.028) was taken to indicate that the fit of the four-parameter model was significantly better than the fit by the three parameter equation for the dataset in the presence of DHPG. Conversely, a $p$ value $>0.05$ indicated that the four-parameter equation did not fit the data significantly better than the three parameter model when MCPG was used to block persistent AHP suppression following DHPG washout.

In the study, we distinguished synchronized discharges in an intracellular recording from isolated events in a single cell by manipulating membrane potential. The rhythm and duration of synchronized discharges are not affected by depolarization or hyperpolarization. Sufficiently hyperpolarized membrane potential blocks firing and reveals trains of sub-

\section{$\leftarrow$}

$\mathrm{Hz}$, as also observed in ictal discharges. Firing of individual action potentials is synchronous across different cells $(\boldsymbol{A c})$. $\boldsymbol{B}$, Time course of duration of synchronized discharges elicited by DHPG. $\boldsymbol{B} \boldsymbol{a}-\boldsymbol{B d}$, Inset, Sample records of synchronized discharges recorded from the same $C A 3$ cell at the indicated time points. Typical response to DHPG includes both ictal-like events (here $3-6 s ; \boldsymbol{B a}$ ) and short bursts of $<1 \mathrm{~s}$. Both burst types persist after washout of DHPG $(\boldsymbol{B} \boldsymbol{b})$, but only the long bursts are reversibly blocked by group I antagonist $M C P G(B C$, Bd). C, Summary data from six cells. Both long (ictal-like, black bars) and short (white bars) discharges persist after DHPG washout (Post DHPG). Long, but not short, discharges are blocked by MCPG. Short discharges averaged $331 \pm 63 \mathrm{~ms}$ in DHPG and were not affected by DHPG washout, application of MCPG, or MCPG washout (Wash MCPG). Ictal-like discharges averaged $4699 \pm 249 \mathrm{~ms}$ in DHPG and were unaffected by DHPG washout (Post DHPG, 40-50 min after wash: $4915 \pm$ $331 \mathrm{~ms})$. In MCPG, for 40 -50 min starting 50 - 60 min after DHPG washout there were no events longer than $1 \mathrm{~s}$. Ictal-like events returned by $10-20$ min after MCPG washout (4591 \pm $142 \mathrm{~ms})$. 
A

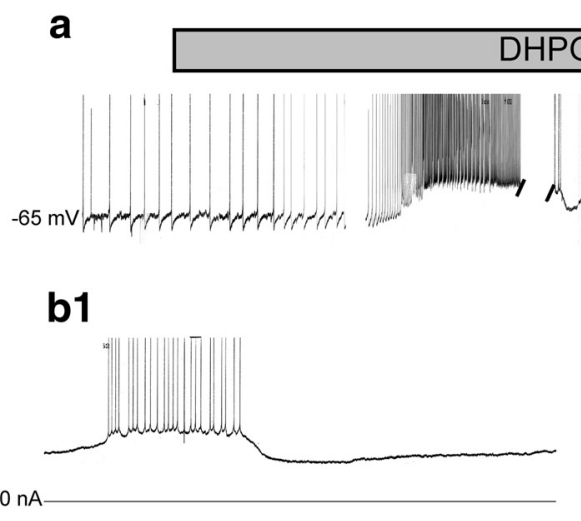

b2

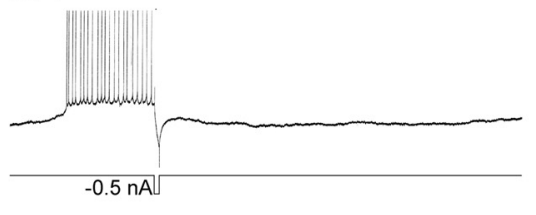

b3

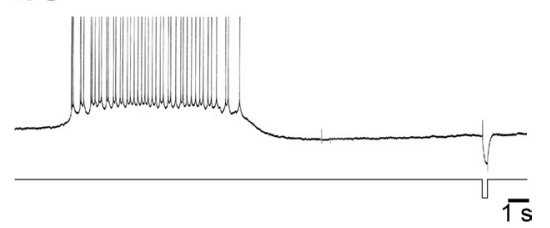

B

a

Control (in TTX) b

DHPG 10 min
C

Post-DHPG $30 \mathrm{~min}$ d

Post-DHPG 60 min

$-54 \mathrm{mV}$ whw

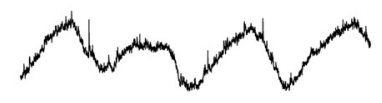<smiles>CCCCCCCCCC</smiles><smiles>CCCCCCCCCCCCC</smiles>

C

a

Control

DHPG

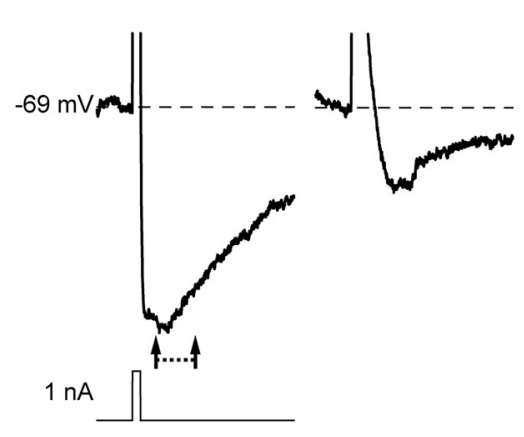

D

a

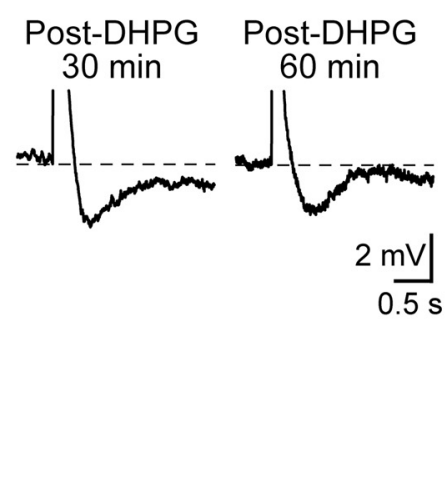

b

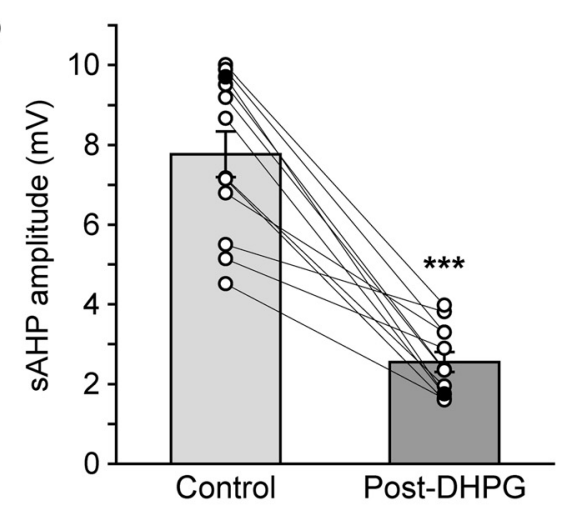

DHPG

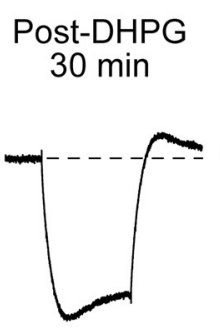
Post-DHPG $60 \mathrm{~min}$
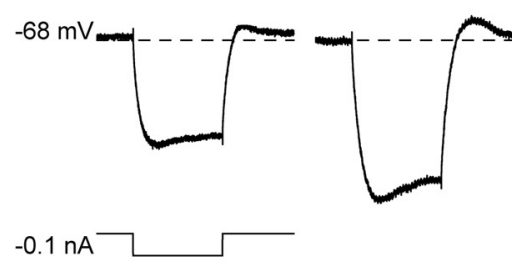

b

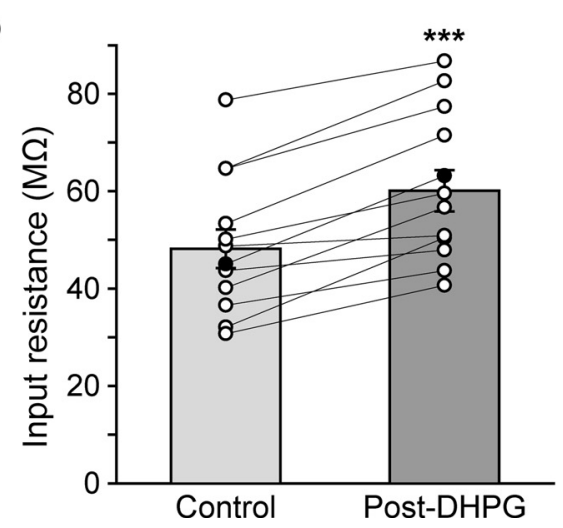

Figure 2. DHPG induces persistent excitatory changes in individual CA3 pyramidal cells pharmacologically isolated from ionotropic glutamatergic input. $A \boldsymbol{a}$, In the presence of the iGluR blockers CNQX (10 $\mu \mathrm{M})$ and (PP (20 $\mu \mathrm{M})$, a CA3 pyramidal cell responds to 30 min application of $30 \mu \mathrm{M}$ DHPG with depolarization, loss of AHP, and (after 5 min) regular bursting. DHPG-induced bursting persists for 30-60 min after DHPG washout (Post-DHPG). $\boldsymbol{A} \boldsymbol{b}$, Similar post-DHPG bursts at faster sweep speed and with hyperpolarizing pulse (lower traces, $-0.5 \mathrm{nA}, 250 \mathrm{~ms}$; $\boldsymbol{A} \boldsymbol{b 2}, \boldsymbol{A} \boldsymbol{b} \mathbf{3})$ that terminates the burst in $\boldsymbol{A} \boldsymbol{b} 2$ but has no effect in $\boldsymbol{A} \boldsymbol{b} 3$. In this and subsequent figures, action potentials are clipped for display purposes. $\boldsymbol{B}, \mathrm{DHPG}$-induced $V_{\mathrm{m}}$ oscillations $(\boldsymbol{B} \boldsymbol{a}, \boldsymbol{B} \boldsymbol{b})$ in TTX $(0.6 \mu \mathrm{M})$. $V_{\mathrm{m}}$ oscillations persist after DHPG washout (BC, Bd).C, Persistent suppression of AHP. C $\boldsymbol{C}$, Slow AHP triggered in a pyramidal cell by action potentials following depolarizing pulse (lower trace, Control; $+1 \mathrm{nA}, 100 \mathrm{~ms}$ ) is suppressed by DHPG and remains suppressed for 30-60 min post-DHPG. The slow AHP amplitude was measured between 200 and $700 \mathrm{~ms}$ post-spike (dashed line between arrows; Materials and Methods). (b , Summary data from 12 cells showing persistent reduction of sAHP amplitude from $7.8 \pm 0.6$ to $2.6 \pm 0.3 \mathrm{mV}$; *** $p<0.001,30-90$ min after DHPG washout. $D$, A persistent increase in pyramidal cell $\mathrm{R}_{\text {in }}$ also contributes to post-DHPG excitation. Da, Hyperpolarizing pulses (lower trace, Control; $-0.1 \mathrm{nA}, 150 \mathrm{~ms}$ ) produce hyperpolarized $V_{\mathrm{m}}$ deflections of increased size in DHPG and $30-60$ min post-DHPG. Bottom right inset, $V_{m}$ responses in control and 60 min post-DHPG shown on a faster time scale. Single exponential (Figure legend continues.) 
threshold synaptic events with patterns like those of synchronized discharges. In contrast, isolated firing activity in single cells is sensitive to membrane potential manipulations. Also, single-cell activities in iGluR antagonists were considered to occur in isolation because excitatory synaptic potentials or D-spike-like electrotonic potentials were not detected at sufficiently hyperpolarized membrane potentials.

\section{Results}

\section{Persistent responses elicited by DHPG in the hippocampal CA3 region}

Figure $1 A$ shows prolonged epileptiform discharges elicited by DHPG in the hippocampal CA3 region. Such discharges persisted after DHPG was washed out, and were reversibly suppressed by the group I mGluR antagonist MCPG (Fig. $1 B, C$ ). Short discharges, of $\leq 1 \mathrm{~s}$, were also evoked by DHPG and also persisted after DHPG washout, but were not suppressed by MCPG (Fig. $1 B, C)$.

In the presence of the AMPA and NMDA receptor blockers CNQX and CPP, synchronous epileptiform discharges elicited by DHPG were blocked. DHPG now evoked unsynchronized regular bursting by individual CA3 neurons (Fig. 2A). Figure $2 \mathrm{Aa}$ shows that DHPG application, in the presence of CNQX and CPP, gradually depolarized a CA3 cell. Within a few minutes, a regular oscillatory firing pattern emerged and persisted after DHPG washout (Fig. 2A, DHPG, Post-DHPG). Figure 2, Aa and $A b 1-3$, shows that oscillatory single cell bursts were sustained by voltage-sensitive plateau potentials that were suppressed by hyperpolarizing pulses (Fig. 2Ab2).

In the presence of TTX $(0.6 \mu \mathrm{M}$; Fig. $2 B)$, rhythmic bursting of single pyramidal cells was suppressed. DHPG application now elicited continuous membrane oscillations in CA3 pyramidal cells observed at membrane potentials between -60 and $-50 \mathrm{mV}$ (Fig. $2 B b$ ). These oscillations persisted after DHPG washout (Fig. $2 B c, B d)$.

In addition to long-term modifications of firing and oscillatory patterns in CA3 pyramidal cells, DHPG application also elicited persistent suppression of the AHP (Fig. 2C) (Young et al., 2008) and persistent increase in $\mathrm{R}_{\text {in }}$ (Fig. 2D). Membrane time constant increased in parallel with $\mathrm{R}_{\text {in }}$ (Fig. $2 D a$, inset).

Of these persistent cellular changes, namely, suppressed AHPs, voltage-dependent depolarizing potentials, and $\mathrm{R}_{\text {in }}$ increases, all of which contribute to increased excitability, AHP suppression was the most robust and the most readily measured under conditions of excitatory synaptic blockade (Young et al., 2004, 2008). Persistent AHP suppression was thus the primary subject of analysis in this study.

\section{Reversal of persistent AHP suppression by group I mGluR antagonists}

Persistent suppression of AHPs was established by treatment of hippocampal slices with DHPG for $30 \mathrm{~min}$. Slices were then bathed in control solution (aCSF) in the presence of the iGluR blockers CNQX and CPP for $\geq 20 \mathrm{~min}$, while AHP sizes were

\footnotetext{
$\leftarrow$

(Figure legend continued.) fits $\left(y=y_{0}+a e^{-t / \tau}\right)$ provided a measure of the membrane time constant $\left(\tau_{\mathrm{m}}\right)$ in control ( $30 \mathrm{~ms}$; top arrow) and 60 min post-DHPG ( $44 \mathrm{~ms}$; bottom arrow). Summary data from 12 cells showed a significant increase of $\tau_{\mathrm{m}}$ from $32.5 \pm 4.3 \mathrm{~ms}$ in control to $40.8 \pm 6.1$ ms post-DHPG $(p<0.01)$. Db, Summary data from 12 cells showing $R_{\text {in }}$ increase from $48.2 \pm 4.0$ to $60.1 \pm 4.3 \mathrm{M} \Omega,{ }^{* * *} p<0.001,30-90 \mathrm{~min}$ after DHPG washout. $R_{\text {in }}$ was calculated as $\Delta V / I(\Delta V$, voltage deflection at the end of the pulse; I, injected current). $C, D$, CNQX and CPP were present throughout. Baseline $V_{m}$ values are indicated to the left of the traces. Stimulus artifacts were digitally reduced in this and subsequent figures.
}

monitored every 10 min. Persistent AHP suppression was monitored 20 min after DHPG washout. Persistent AHP suppression was repeatedly reversed by coapplication of the mGluR1 and mGluR5 antagonists, LY 367385 and MPEP, respectively (Fig. $3 A$ ). Furthermore, persistent suppression of medium and slow AHPs was similarly reversed by the broad-spectrum group I mGluR antagonist MCPG (Fig. $3 B$ ). Figure 3, $B b$ and $B d$, summarizes data for mAHPs and sAHPs, respectively. The average mAHP amplitude (as a percentage of control size) at least $20 \mathrm{~min}$ after DHPG washout was reduced to $-22 \pm 21 \%(n=8 ; p<$ 0.001 vs control; Fig. $3 \mathrm{Bb}$ ). During treatment with MCPG, mAHP increased to $97 \pm 20 \%(n=5 ; p<0.001$ vs post-DHPG; Fig. $3 \mathrm{Bb}$ ) from its post-DHPG amplitude and was resuppressed to $3 \pm 3 \%$ of control $(n=5 ; p<0.001)$ upon MCPG washout. During treatment with MCPG, the slow AHP rose to $103 \pm 7 \%$ from its persistently suppressed amplitude $(n=6$; $p<0.001$; Fig. $3 B d)$ and decreased to $45 \pm 5 \%$ after MCPG washout $(n=6 ; p<0.001)$.

Figure $3 C$ shows that group I mGluR subtypes mGluR1 and mGluR5 do not contribute equally to the maintenance of AHP suppression. Medium and slow AHPs from the same cell are shown in Figure 3, $\mathrm{Ca}$ and $\mathrm{Cc}$, respectively. AHPs were persistently suppressed by 30 min treatment with DHPG (Fig. 3C, PostDHPG). Subsequent addition of the mGluR5 blocker MPEP had a small (compared with mGluR1 blockers) but a significant effect on AHP size (Fig. 3C, MPEP). In contrast, LY 367385, a selective mGluR1 blocker, caused a significantly larger rescue of persistently suppressed AHPs (Fig. 3Ca,Cc, LY). Figure 3, $C b$ and $C d$, depicts summary data of the effect of MPEP, LY 367385, and the noncompetitive mGluR1 antagonist CPCCOEt on persistently suppressed medium (Fig. 3Cb) and slow (Fig. 3Cd) AHPs. The amplitude of persistently suppressed mAHPs was $11 \pm 4 \%$ of control $(n=23 ; p<0.001)$. During MPEP, mAHPs were $29 \pm$ $7 \%$ of control $(n=8)$. The persistently suppressed sAHP before MPEP was reduced to $24 \pm 3 \%$ of control $(n=21 ; p<0.001)$, and $34 \pm 4 \%(n=8)$ of control in the presence of MPEP, indicating significant recovery $(p<0.001$ vs post-DHPG). On the other hand, LY 367385 markedly increased the amplitude of persistently suppressed AHPs, as did CPCCOEt. LY 367385 increased mAHP amplitude to $75 \pm 9 \%$ at $50 \mu \mathrm{M}(n=4 ; p<0.001)$ and to $73 \pm 11 \%$ at $100 \mu \mathrm{M}(n=6 ; p<0.001)$ from the persistently suppressed level. The sAHP recovered to $76 \pm 9 \%(n=4$; $p<0.001$ vs post-DHPG) during treatment with LY 36738550 $\mu \mathrm{M}$ and to $76 \pm 15 \%(n=5 ; p<0.001$ vs post-DHPG $)$ with LY $367385100 \mu \mathrm{M}$. CPCCOEt $(100 \mu \mathrm{M})$ rescued the suppressed mAHP to $71 \pm 6 \%(n=4 ; p<0.001)$ and the suppressed sAHP to $76 \pm 10 \%(n=5 ; p<0.001)$ of control. Coapplication of MPEP $(50 \mu \mathrm{M})$ and LY $367385(100 \mu \mathrm{M})$ had a significant additional effect over either of the antagonists alone, with recovery of the mAHP to $96 \pm 4 \%$ of control $(n=9)$ - significantly greater than that in MPEP $(p<0.001)$ or LY $367385(p<0.01$; Fig. $3 C b)$ alone. Similarly, sAHP recovered to $104 \pm 6 \%$ of control $(n=7)$ during coapplication - a significantly greater recovery than in MPEP $(p<0.001)$ or LY 367385 ( $p<0.01$; Fig. 3Cd) alone.

Finally, the rescue of persistently suppressed AHPs by LY $367385100 \mu \mathrm{M}$ was significantly greater than that by MPEP 50 $\mu \mathrm{M}(p<0.001$ for $\mathrm{mAHP}$ and sAHP $)$.

\section{Role of DHPG washout in persistent AHP suppression}

To evaluate a possible role of incomplete DHPG washout in persistent AHP suppression, we compared the efficacy of the group I antagonist MCPG against AHP suppression directly elicited by DHPG versus that against persistent responses maintained after 
A

a

Control sAHP Post-DHPG MPEP + LY Wash MPEP + LY

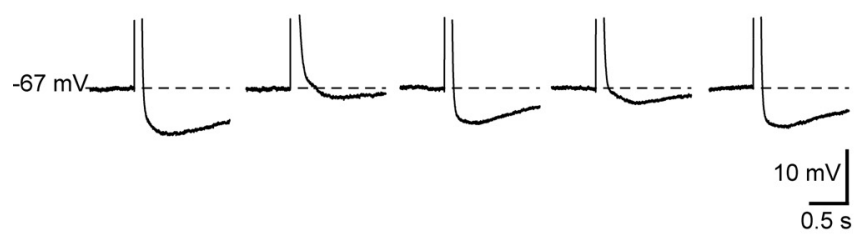

B

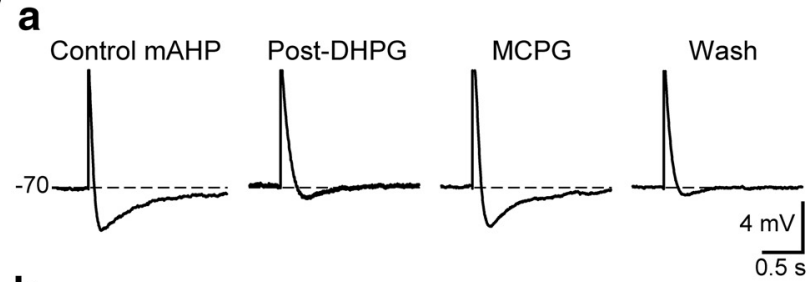

b

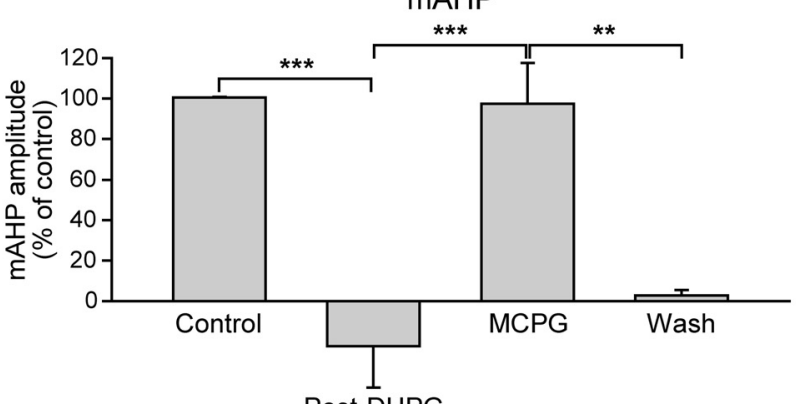

C

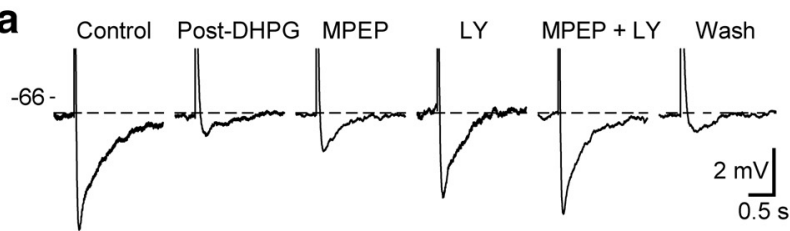

b

mAHP

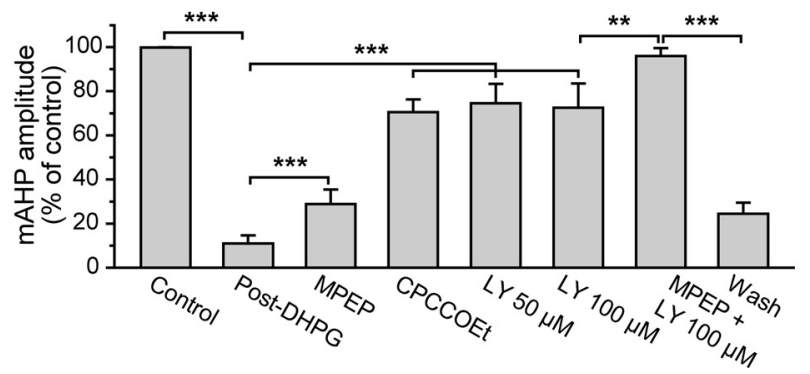

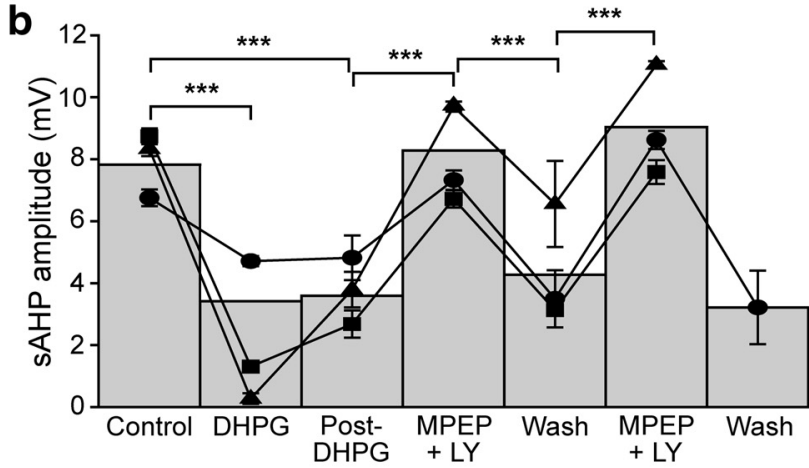

C

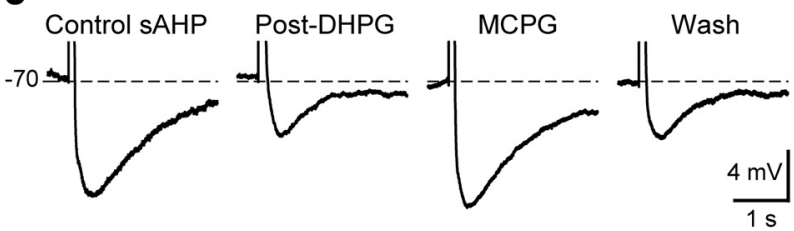

d

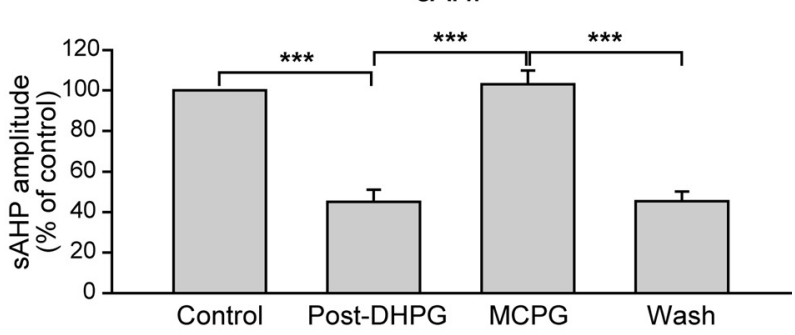

C

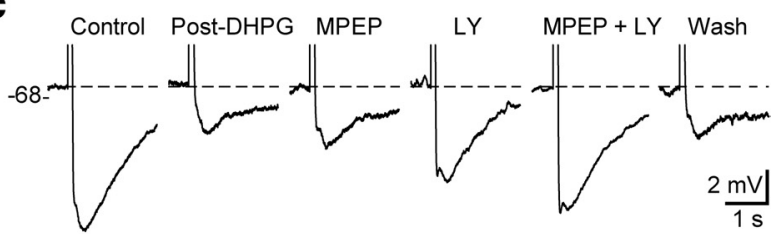

d

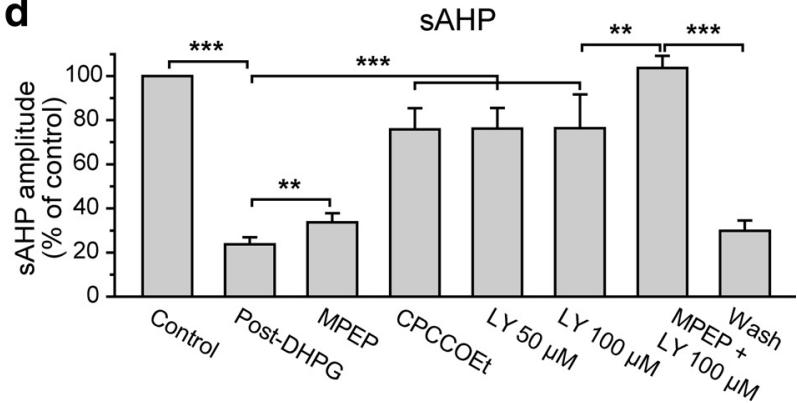

Figure 3. Rescue of persistently suppressed AHP by group I mGluR blockers. Aa, Example traces of $\mathrm{sAHPs}$ following $100 \mathrm{~ms}$ depolarizations with $0.8 \mathrm{nA}$ from a baseline of $-67 \mathrm{mV}$. Traces shown are Control (10 $\mu \mathrm{M}$ CNQX and $20 \mu \mathrm{M}$ CPP were present throughout the experiment), 15 min after washout of a 30 min treatment with $45 \mu \mathrm{m}$ DHPG (Post-DHPG), 4 min after application of $50 \mu \mathrm{m}$ MPEP plus $100 \mu \mathrm{M}$ LY 367385 (MPEP + LY), 27 min after washout of MPEP and LY 367385 (Wash), and 6 min after reapplication of MPEP and LY 367385 (MPEP + LY, last record shown). Traces shown are averages of three sweeps. Ab, Summary of three experiments in which repeated applications of MPEP and LY 367385 were made to CA3 cells treated with $30-45 \mu \mathrm{M}$ DHPG for 30 min. Shown for each of the three cells are average amplitudes of $2-4$ sAHPs triggered by action potential bursts resulting from $100 \mathrm{~ms}$ depolarizing pulses under control, during DHPG, after DHPG washout (Post-DHPG), repeated MPEP and LY 367385, and wash conditions. Error bars on individual points are SEs of 2- 4 measurements under that condition. Gray bars are the averages for all cells under a given condition. Two-way ANOVA and Student-Newman-Keuls post-tests showed significant treatment effects (*** $p<0.001$ between data groups indicated by brackets). Applications of MPEP plus LY 367385 repeatedly brought the suppressed AHPs back to control amplitudes, while washout of group I mGluR blockers returned AHP amplitudes to suppressed levels. $\boldsymbol{B}$, Examples of mAHPs $(B a)$ triggered by 4 ms depolarizations (single action potentials), or sAHPs $(\boldsymbol{B C})$ triggered by $100 \mathrm{~ms}$ depolarizing pulses. Slices were then exposed to $30-45 \mu \mathrm{M} \mathrm{DHPG} \mathrm{for} 30 \mathrm{~min}$, and DHPG was washed out for at least $20 \mathrm{~min}$ (Post-DHPG) before application of $500 \mu \mathrm{M}$ MCPG. The group I mGluR antagonist was then washed out, and AHPs were recorded once again (Wash). Holding potentials

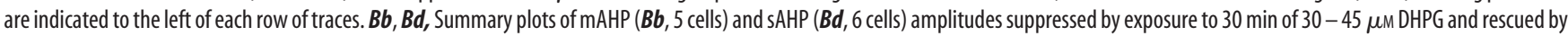
$500 \mu \mathrm{M}$ MCPG. AHP amplitudes under each condition were averaged (9 sweeps, mAHPs; $2-4$ sweeps, sAHPs) and normalized to the control amplitude in that cell. Average (Figure legend continues.) 
DHPG washout. We anticipated that the effect of MCPG on AHP suppression observed under these two conditions would be the same if DHPG elicited the suppression in both instances.

The effectiveness of MCPG (Fig. 4A, red bars) in blocking direct sAHP suppression by DHPG (Fig. $4 A$, red circles) was examined by applying the antagonist to the slice in varying concentrations while the effect on sAHP size of brief $(<3 \mathrm{~min})$ DHPG applications was measured (Fig. 4A). Applications of DHPG were kept brief (Fig. $4 A$, gray bars) and were followed by $\geq 15$ min of wash in the absence of DHPG to allow full recovery of sAHP amplitudes between DHPG treatments (Young et al., 2004).

Second, to obtain the relationship describing the effectiveness of MCPG in reversing persistent AHP suppression, we established a persistently suppressed sAHP using a $30 \mathrm{~min}$ exposure to DHPG (Young et al., 2008) (Fig. 4B, DHPG, gray bar). DHPG was then washed out for at least $20 \mathrm{~min}$ (Fig. 4B, Post-DHPG) and, after verifying the persistent suppression of the sAHP (18.6\% of control), MCPG was added at a concentration of between 50 and $500 \mu \mathrm{M}$ (Fig. 4B, MCPG, blue bars). MCPG was then washed out for $\geq 20 \mathrm{~min}$ and reapplied using a different concentration. Amplitude of the sAHP was monitored throughout (Fig. $4 B$, blue circles).

Normalized sAHP amplitudes (as a percentage of maximum block) from both types of experiments (Fig. 4C, in the presence of DHPG, red circles, and after washout of DHPG, blue circles) were plotted on a semilog scale and were fitted by Hill equations (Fig. $4 C$; Materials and Methods). AHP amplitudes were fit either as one combined dataset or as two separate datasets from the two experiments, and the resulting fits were compared using an $F$ test (Materials and Methods). The resulting $p$ value $\left(7.15 \times 10^{-6}\right)$ indicated a statistically significant improvement of fit by treating the two datasets separately, and thus suggested a significant difference in the dose-response curves under the two conditions.

An additional comparison of sAHP measurements made in the presence of DHPG and after washout of DHPG was made by fitting both sets of data with both three-parameter and four-parameter Hill equations (Materials and Methods). The fit of each dataset by both Hill equations was then compared using $F$ tests. The dose-response data for the reversal of AHP suppression in the presence of DHPG was significantly better fit by the four-parameter than by the three-parameter Hill equation ( $p=0.028$ ). In contrast, MCPG reversal of persistent AHP suppression was not significantly better fit by the fourparameter over the three-parameter model. This suggested that different populations of receptors might be involved in the two cases, with the receptor population underlying the persistent response being relatively more homogeneous.

\footnotetext{
(Figure legend continued.) control $\mathrm{mAHP}$ amplitude was $-3.2 \pm 0.3 \mathrm{mV}, n=8$, and average control sAHP amplitude was $-7.3 \pm 0.4 \mathrm{mV}, n=9$. Normalized AHPs for each cell under each condition were then averaged and are plotted \pm SEM. Comparisons were made using one-way ANOVA and Student-Newman-Keuls post-tests $\left({ }^{* *} p<0.01\right.$; $\left.{ }^{* * *} p<0.001\right)$. The negative percentage amplitude of the mAHP in $\boldsymbol{B} \boldsymbol{b}$, Post-DHPG, reflects a DHPG-induced afterdepolarization (Young et al., 2004). C, Examples of medium (Ca) and slow (Cc) AHPs in control, persistently suppressed (Post-DHPG), MPEP (50 $\mu \mathrm{M})$, LY 367385 (LY; $100 \mu \mathrm{M})$, MPEP plus LY 367385 , or wash of both group I mGluR blockers. $\boldsymbol{C b}$, $\boldsymbol{C d}$, Summary data of mAHP and sAHP amplitudes in control (mAHP, $-3.3 \pm 0.2 \mathrm{mV}, n=23 ; \mathrm{sAHP},-7.0 \pm 0.5 \mathrm{mV}, n=21$ ), after persistent AHP suppression by $30-50 \mu \mathrm{m}$ DHPG (Post-DHPG: mAHP, $11 \pm 4 \%$ of control, $n=$ $23, p<0.001$; sAHP, $24 \pm 3 \%$ of control, $n=21, p<0.001$ ), in the presence of group I mGluR antagonists (MPEP $50 \mu \mathrm{m}$, CPCCOEt $100 \mu \mathrm{m}$, LY 367385 at 50 or $100 \mu \mathrm{m}$, MPEP $50 \mu \mathrm{m}$ plus LY $367385100 \mu \mathrm{M}$ ) and after drug washout (Wash). Comparisons were made using one-way ANOVA and Student-Newman-Keuls post-tests $\left({ }^{* *} p<0.01 ;{ }^{* * *} p<0.001\right)$.
}

\section{Is elevated glutamate involved in persistent AHP suppression?}

In view of the lack of evidence that persistent AHP suppression results from continued occupation of group I mGluRs by DHPG following DHPG washout (see above), another possibility is that the receptors are stimulated by glutamate (Bandrowski et al., 2003). The activity increase that accompanies treatment with DHPG might lead to increased glutamate release that becomes self-sustaining. Increased glutamate levels have been shown in rat hippocampus following kindling (Matveeva et al., 2012) and could result from activity increases occurring in DHPG. We explored this possibility by using two different methods to reduce glutamate release.

In the first experiment, TTX was used to block spike-mediated release of glutamate. Since $\mathrm{Na}^{+}$spikes are blocked in TTX, sAHPs following evoked $\mathrm{Ca}^{2+}$ spikes were monitored (Fig. 5Aa). Slow AHPs following $\mathrm{Ca}^{2+}$ spikes in TTX averaged $-4.0 \pm 1.3$ $\mathrm{mV}(n=3)$. DHPG reduced the sAHP to $30 \pm 3 \%(n=3 ; p<$ 0.001 of control; Fig. $5 A b$ ). Persistent sAHP suppression was observed following DHPG washout $(28 \pm 5 \% ; n=3 ; p<0.001$; 25-30 min after DHPG washout). In the presence of TTX, the persistently suppressed sAHP was also reversibly rescued by MCPG (in MCPG, $76 \pm 15 \%, n=3, p=0.005$; after MCPG washout, $41 \pm 9 \%, n=3, p=0.003)$.

The second experiment used a low $\mathrm{Ca}^{2+}$, high $\mathrm{Mn}^{2+}$ solution (Materials and Methods) to reduce synaptic release of glutamate. Since this solution eliminated the $\mathrm{Ca}^{2+}$-dependent sAHP, mAHPs were monitored (Fig. $5 \mathrm{Ba}$ ). In the presence of low $\mathrm{Ca}^{2+}$, high $\mathrm{Mn}^{2+}$ solution, the average mAHP amplitude was $-3.24 \pm$ $0.35 \mathrm{mV}(n=4)$. DHPG reduced the mAHP to $10 \pm 5 \%$ of control $(n=4 ; p<0.001$; Fig. $5 B b)$. In the continued presence of low $\mathrm{Ca}^{2+}$, high $\mathrm{Mn}^{2+}$ solution, mAHP suppression persisted after DHPG washout (30-40 min after DHPG washout, $20 \pm 9 \%$ of control; $n=4 ; p<0.001)$. Persistently suppressed mAHPs in low $\mathrm{Ca}^{2+}$, high $\mathrm{Mn}^{2+}$ solution were also reversibly rescued by MCPG (in MCPG, $94 \pm 3 \%$ of control, $n=4, p<0.001$; after MCPG washout, $9 \pm 1 \%$ of control; $n=4 ; p<0.001$ ).

The above experiments show that DHPG-induced persistent AHP suppression was not affected by treatments that reduced glutamate release from synapses. However, the possibility remained that nonsynaptic glutamate release (Fellin et al., 2004; Pirttimaki et al., 2011) following treatment with DHPG had raised ambient glutamate levels to the point that group I mGluRs were continuously activated. We addressed this point by assuming that glutamate levels high enough to continuously activate group I mGluRs would also activate AMPA and/or NMDA receptors to produce cell depolarization and, therefore, that blocking these active iGluRs with CNQX and CPP would lead to membrane hyperpolarization. Thus, the effect of CNQX and CPP on $V_{\mathrm{m}}$ was monitored before and after $30 \mathrm{~min}$ treatment with DHPG (Fig. 6).

Figure 6, $A a$ and $A b$, shows that application of CNQX plus CPP had no effect on $V_{\mathrm{m}}$ either before or after 30 min treatment with DHPG. Nor did CNQX plus CPP affect control or persistently suppressed sAHP amplitudes. MCPG on the other hand, while having no effect before DHPG (Fig. 6Ba), both rescued persistently suppressed AHPs and markedly hyperpolarized the $V_{\mathrm{m}}$ after washout of DHPG (Fig. $6 B b$ ). Figure 6, $A c$ and $B c$, summarizes $V_{\mathrm{m}}$ measurements for the various treatments. Measured with respect to the mean of membrane potentials before and after the addition of blockers, the hyperpolarization caused by MCPG after a 30 min treatment with DHPG was $-5.8 \pm 0.6 \mathrm{mV}(n=4$; $p<0.001$; Fig. $6 B c$ ), while the membrane potential during CNQX 
A
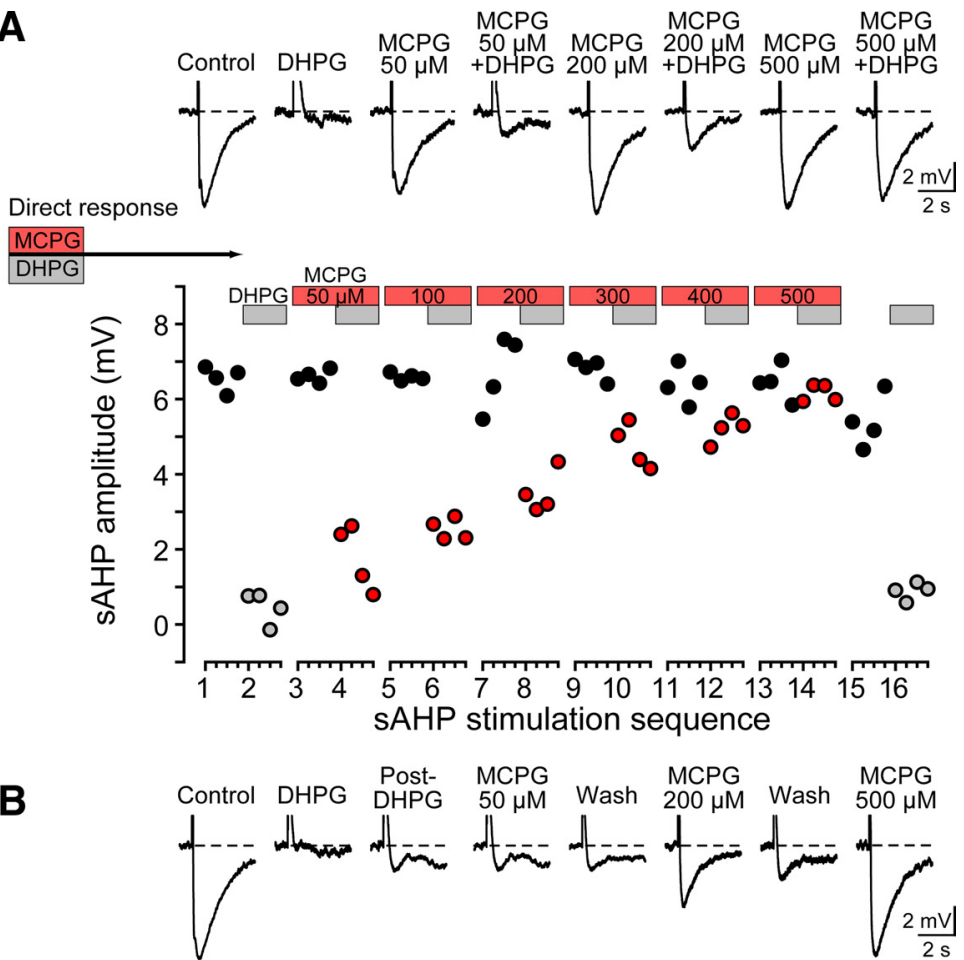

Persistent response DHPG

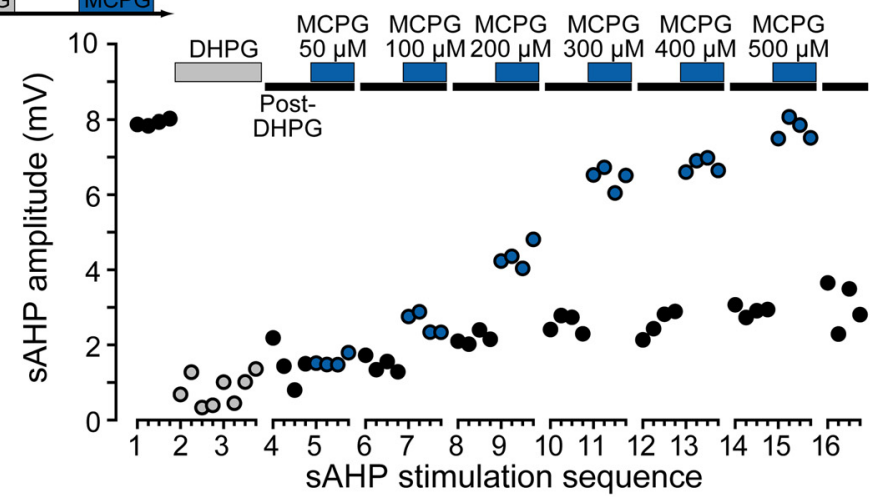

C

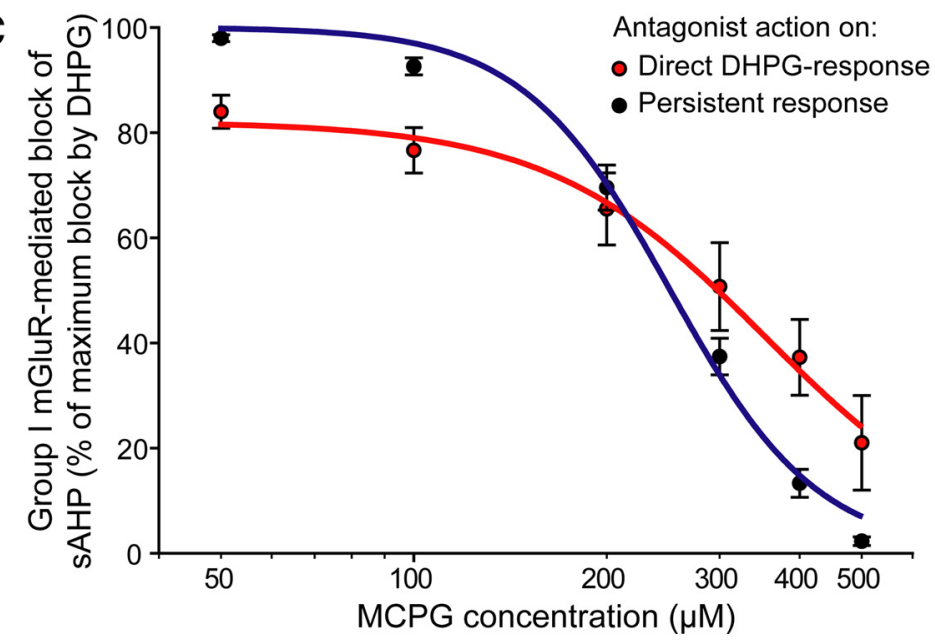

Figure 4. The DHPG-induced direct suppression of SAHP and the persistent suppression of sAHP following DHPG are antagonized by MCPG with different dose-response profiles. $A$, The effects of MCPG on the sAHP suppression induced by direct application of DHPG (direct response) were examined by coapplying the two agents (inset, experimental paradigm). Top records, Example traces of $s$ AHPs following a train of four action potentials, each elicited by a 4 ms depolarizing pulse of $+1.6 \mathrm{nA}$ at $15 \mathrm{~ms}$ intervals from a baseline of $-70 \mathrm{mV}$ (dashed lines), recorded from the same neuron in control conditions (Control: $10 \mu \mathrm{M}$ CNQX and $20 \mu \mathrm{N}$ (PP), during a 5 min-application of $45 \mu \mathrm{M}$ DHPG (DHPG), following DHPG washout and in the presence of MCPG at increasing plus CPP exposure was unchanged $(-68.7 \pm 0.7 \mathrm{mV} ; n=7$; Fig. $6 \mathrm{Ac})$. Before treatment with DHPG, neither MCPG nor CNQX plus CPP had a significant effect on membrane potential (Fig. $6 B a, A a$, Control). Control membrane potential before MCPG was $-68.7 \pm 1.2 \mathrm{mV}(n=$ 4). Membrane potential in MCPG was unchanged at $-69.1 \pm 1.2 \mathrm{mV}(n=4)$, and after MCPG washout was $-68.4 \pm$ $1.1 \mathrm{mV}(n=4$; Fig. $6 B c$, gray bars). Membrane potential was $-68.3 \pm 0.6 \mathrm{mV}(n=$ 8 ) before CNQX and CPP, $-67.5 \pm 0.7$ $\mathrm{mV}(n=8)$ during CNQX and CPP, and $-67.7 \pm 0.6 \mathrm{mV}(n=8)$ after CNQX and CPP were washed out (Fig. 6Ac, gray bars).

Since NMDA receptors show higher sensitivity to glutamate than AMPA receptors (Lalo et al., 2006) and their conductance is reduced at resting and hyperpolarized membrane potentials (Johnson and Ascher, 1990), we examined the effects of CPP in neurons post-DHPG at various membrane potentials. Figure $6 \mathrm{Cb}$ shows summarized data indicating that $\mathrm{CPP}$ application did not significantly affect the membrane potential even at depolarized levels.

The lack of effect of CNQX and CPP indicates a negligible contribution to the

\footnotetext{
concentrations (MCPG), and during DHPG applied in the presence of $M C P G(M C P G+D H P G)$. Traces shown are averages of four sweeps. Bottom plot, Amplitudes of SAHP measured in control (first 4 black circles), during 5 min application of $30 \mu \mathrm{M}$ DHPG (gray circles), following DHPG washout and in the presence of MCPG at increasing concentrations (red bars, black circles), and during DHPG applied in the presence of MCPG (red circles). Breaks of the $x$-axis indicate intervals of $10-20$ min following DHPG washout. $\boldsymbol{B}$, The effects of MCPG on the persistent sAHP suppression (Persistent response) were examined by applying MCPG following washout of a $30 \mathrm{~min}$ application of DHPG (inset, experimental paradigm). Top records, Example traces of sAHPs following $100 \mathrm{~ms}$ depolarizations of $+0.8 \mathrm{nA}$ from a baseline of $-67 \mathrm{mV}$ recorded from the same neuron in control conditions (Control: $10 \mu \mathrm{M}$ CNQX and $20 \mu \mathrm{M}(P P)$, in $45 \mu \mathrm{M}$ DHPG (DHPG), and following DHPG washout in the absence (Wash) and in the presence of MCPG applied at increasing concentrations (MCPG). Traces shown are averages of four sweeps. Bottom plot, Amplitudes of sAHP measured in control (first 4 black circles), at 20 min of perfusion with $45 \mu \mathrm{M}$ DHPG (gray circles), following DHPG washout (black bars, black circles), and in the presence of MCPG applied at increasing concentrations (blue circles). C, Summary data of dose-response relationships of MCPG-mediated antagonism of the direct (red plot) and persistent (blue plot) suppression of SAHP. Symbols and bars are means \pm SEM of SAHP suppression normalized to maximum suppression by DHPG recorded in the absence of MCPG for the direct response $(n=4-5$ per data point) and for the persistent response ( $n=3-6$ per data point). The direct response data are fitted with a fourparameter logistic equation (red line), and the persistent response data are fitted with a three-parameter logistic equation (blue line).
} 
A

a

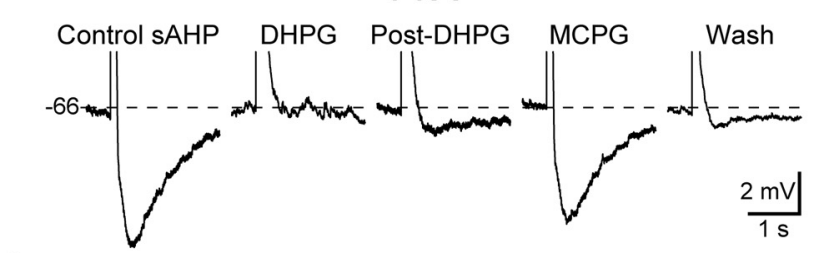

b

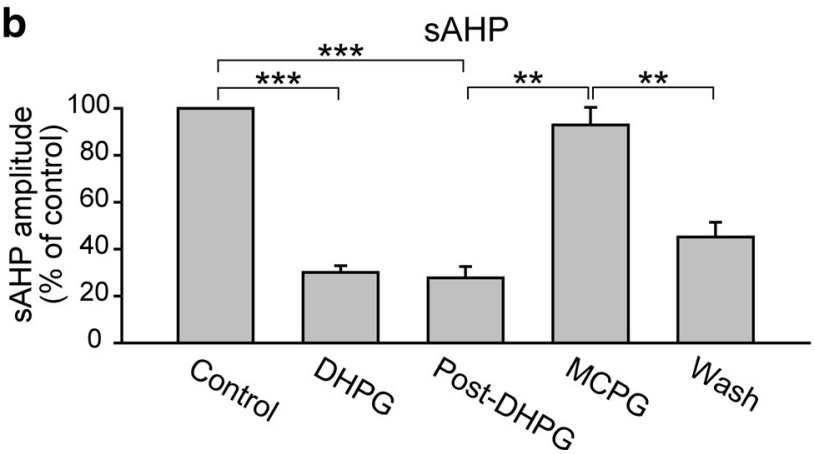

B

a

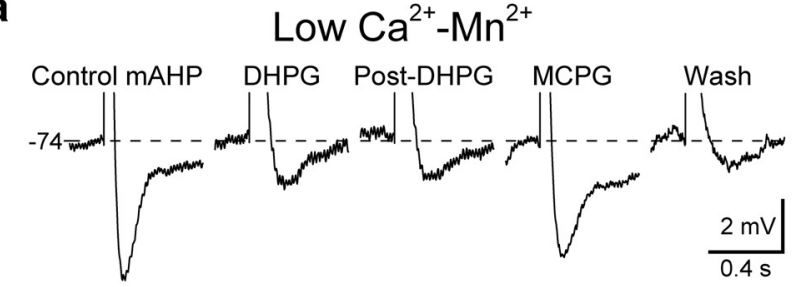

b

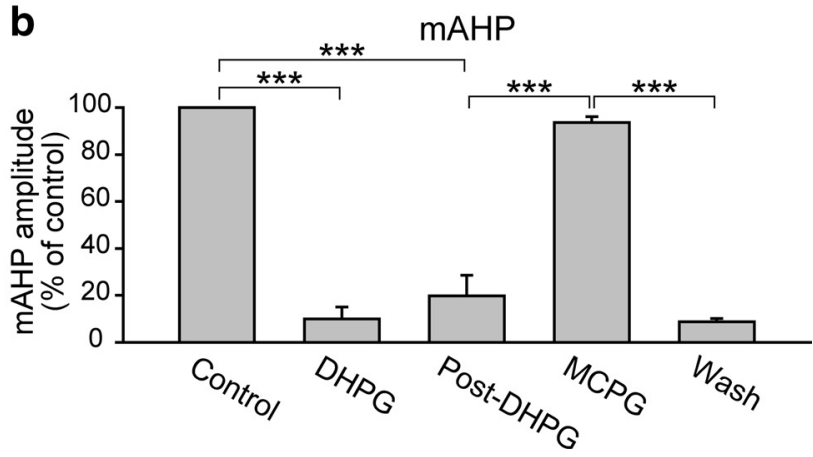

Figure 5. DHPG causes persistent AHP suppression in the presence of TTX, or $\mathrm{Mn}^{2+}$ and low $\mathrm{Ca}^{2+}$. Aa, Examples of slow AHPs following $\mathrm{Ca}^{2+}$ spikes triggered by $1.8 \mathrm{nA}, 100 \mathrm{~ms}$ depolarizing pulses in the presence of $0.6 \mu \mathrm{m}$ TTX throughout. Slow AHPs were recorded in Control solution (containing TTX, but not CNQX and (PP), during 30 min treatment with $30 \mu \mathrm{M} \mathrm{DHPG} \mathrm{(and} \mathrm{TTX),} \mathrm{and}$ 21 min after washout of DHPG (Post-DHPG). TTX had no effect on the persistence of DHPG-induced sAHP suppression. TTX also had no effect on the reversible rescue of the sAHP by $500 \mu \mathrm{m}$ MCPG (MCPG, Wash). Baseline $V_{m}$ is indicated to the left. Stimulus artifacts were digitally reduced. Ba, mAHPs recorded following single action potentials triggered by $4 \mathrm{~ms}, 2 \mathrm{nA}$ depolarizing pulses in the presence of $0.2 \mathrm{~mm} \mathrm{Mn}^{2+}$ and $0.5 \mathrm{~mm} \mathrm{Ca}^{2+} . \mathrm{Mn}^{2+}$ and low $\mathrm{Ca}^{2+}$ solution did not hinder persistent mAHP suppression by DHPG (DHPG, Post-DHPG). Nor did Mn ${ }^{2+}$ and low Ca ${ }^{2+}$ solution hinder the reversible rescue of the suppressed mAHP by $400 \mu \mathrm{M} M C P G(M C P G$, Wash). Seven to nine sweeps were averaged per trace. Holding potentials are indicated by numbers to the left of traces. $A \boldsymbol{b}$, $\boldsymbol{B} \boldsymbol{b}$, Summary plots of experiments in $\operatorname{TTX}\left(\boldsymbol{A} \boldsymbol{b}, n=3\right.$ cells) or $\mathrm{Mn}^{2+}$ and low Ca ${ }^{2+}$ solution ( $\boldsymbol{B} \boldsymbol{b}, n=4$ cells). Normalized AHP amplitudes are plotted with respect to control amplitude for each cell $\left({ }^{* *} p<0.01 ;{ }^{* * *} p<0.001\right.$; one-way ANOVA followed by Student-Newman-Keuls post-tests).

resting potential by active iGluRs. The hyperpolarization caused by MCPG on the other hand, indicates that active mGluRs persistently depolarize $V_{\mathrm{m}}$ following treatment with DHPG. The DHPG-induced persistent depolarization could result from DHPG-induced $I_{\mathrm{mGluR}(\mathrm{V})}$ (Bianchi et al., 2009) or from persistently reduced potassium leak conductance (Bianchi et al., 1999; Chuang et al., 2001), or both. Together, the insensitivity of persistent AHP suppression to reduced synaptic release of glutamate and the absence of evidence for effectively increased ambient glutamate levels strongly suggest that elevated glutamate levels are not required for DHPG-induced persistent suppression of the AHP.

\section{Effects of mGluR1 antagonist on post-DHPG cell conductance and inward current}

Figure 2 shows that the $\mathrm{R}_{\text {in }}$ increase following DHPG treatment persists after DHPG washout. Figure 7, $A a$ and $A b$, illustrates voltage-clamp experiments showing that, like persistently suppressed AHPs, the persistently suppressed resting leak current $\left(I_{\text {leak }}\right)$ is also rescued by LY 367385 . The amplitude of $I_{\text {leak }}$ was reduced after DHPG washout from $601 \pm 36$ to $416 \pm 47 \mathrm{pA}(n=$ $9 ; p<0.001$; Fig. 7Ab). LY 367385 increased the suppressed $I_{\text {leak }}$ to $546 \pm 32 \mathrm{pA}(n=9 ; p<0.001)$, and washout of LY 367385 again caused $I_{\text {leak }}$ to be suppressed $(441 \pm 38 \mathrm{pA} ; n=9 ; p<$ $0.001)$. Thus, $R_{\text {in }}$ is persistently elevated, favoring an increase in cell firing.

In the same series of experiments, persistently suppressed $I_{\mathrm{AHP}}$ was also monitored and was shown to be rescued by LY 367385 (Fig. $7 \mathrm{Ba}, \mathrm{Bb}$ ). The amplitude of $I_{\mathrm{AHP}}$ was reduced after DHPG washout from $136 \pm 5$ to $27 \pm 7 \mathrm{pA}(n=8 ; p<0.001$; Fig. $7 B b)$. LY 367385 increased the suppressed $I_{\mathrm{AHP}}$ to $112 \pm 17 \mathrm{pA}(n=8$; $p<0.001)$ and washout of LY 367385 resuppressed $I_{\mathrm{AHP}}$ to $29 \pm$
$6 \mathrm{pA}(n=8 ; p<0.001)$. Thus, resting membrane conductance parallels $I_{\mathrm{AHP}}$ in its persistent suppression following DHPG treatment and in its reversibility with mGluR1 blockade.

Persistent DHPG-induced voltage oscillations (Fig. 7Ca, PostDHPG) in neurons recorded in TTX were also reversibly suppressed by the mGluR1 antagonist LY 367385 (Fig. 7Ca, LY, Wash). Previous studies described a persistent voltagedependent inward current elicited by DHPG $\left(I_{\text {mGluR(V) }}\right)$ that sustains membrane oscillations in CA3 pyramidal cells (Chuang et al., 2000, 2001; Bianchi et al., 2009). $I_{\mathrm{mGluR}(\mathrm{V})}$ has an activation threshold of approximately $-70 \mathrm{mV}$ and is non-inactivating. $I_{\mathrm{mGluR}(\mathrm{V})}$ was elicited using depolarizing steps to $-40 \mathrm{mV}$ from a holding potential of $-125 \mathrm{mV}$ (Fig. $7 \mathrm{Cb}$; see also Bianchi et al., 2009). Like group I mGluR-induced voltage oscillations, $I_{\mathrm{mGluR}(\mathrm{V})}$ was reversibly suppressed by LY 367385 (Fig. 7Cb, LY, Wash). Figure $7 C c$ summarizes data from six experiments in which LY 367385 reversibly reduced the $I_{\mathrm{mGluR}(\mathrm{V})}$ that persisted after DHPG washout. Persistent $I_{\text {mGluR(V) }}$ was $148 \pm 14$ pA 45 min after DHPG washout (Fig. 7Cc, Post-DHPG; $n=6$ ); the current was reduced to $40 \pm 8 \mathrm{pA}$ by LY 367385 (Fig. $7 C c, n=6, p<0.001$, compared with Post-DHPG), and recovered to $146 \pm 15 \mathrm{pA}$ when LY 367385 was washed out (Fig. $7 C c, n=6, p<0.001$, compared with LY).

\section{Sensitivity of DHPG-induced epileptiform discharges to} group I mGluR antagonists in $\mathrm{Fmr}^{-/-}$preparations

The observed differential effects of mGluR1 and mGluR5 antagonists on persistent single cell excitability changes induced by DHPG in CA3 cells can be compared with those reported previously on persistent DHPG-induced epileptiform discharges in hippocampal slices where the mGluR1 antagonist is more effective in suppressing the maintained epileptiform discharges than 
A

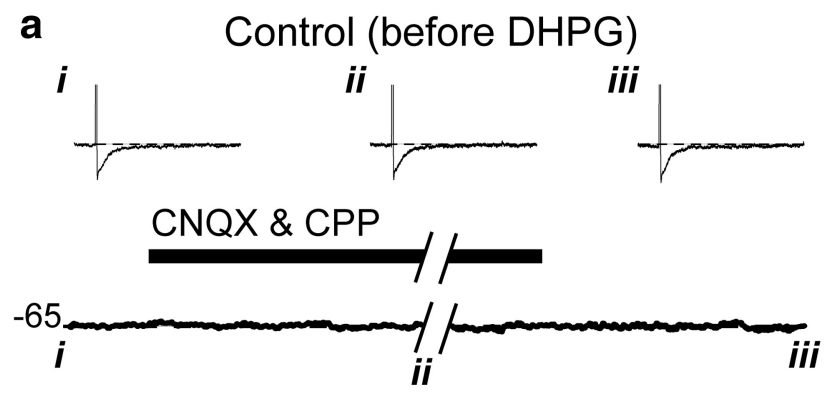

b

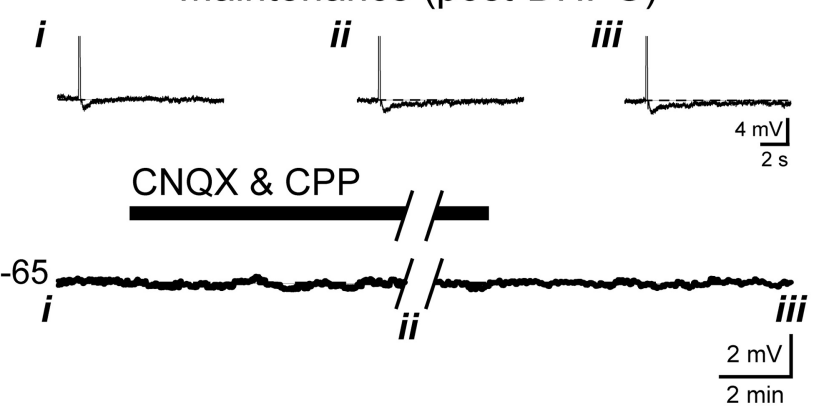

C

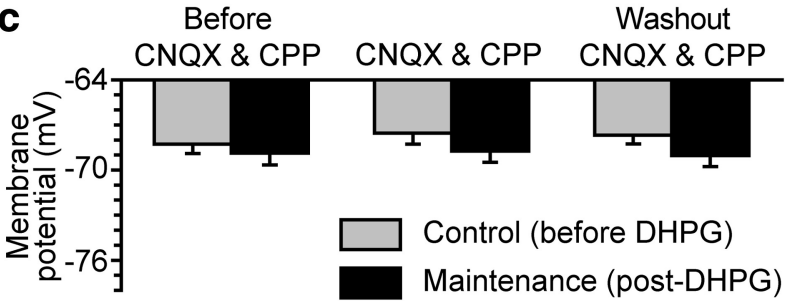

C

a

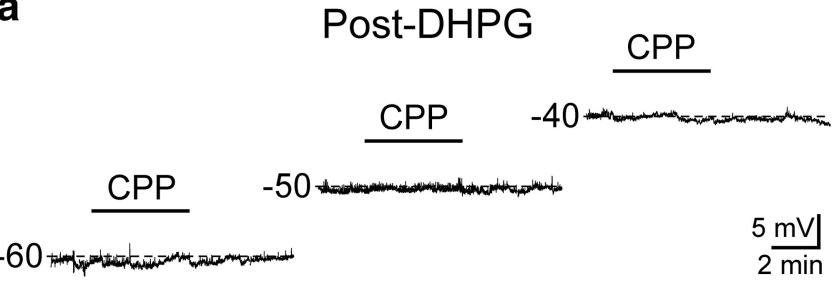

B

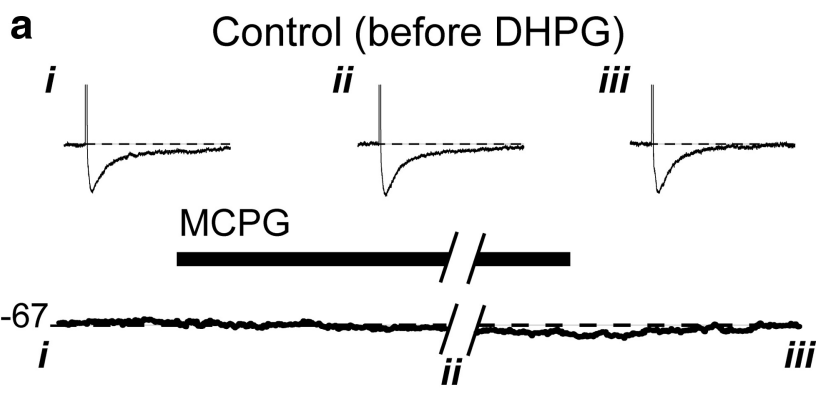

b
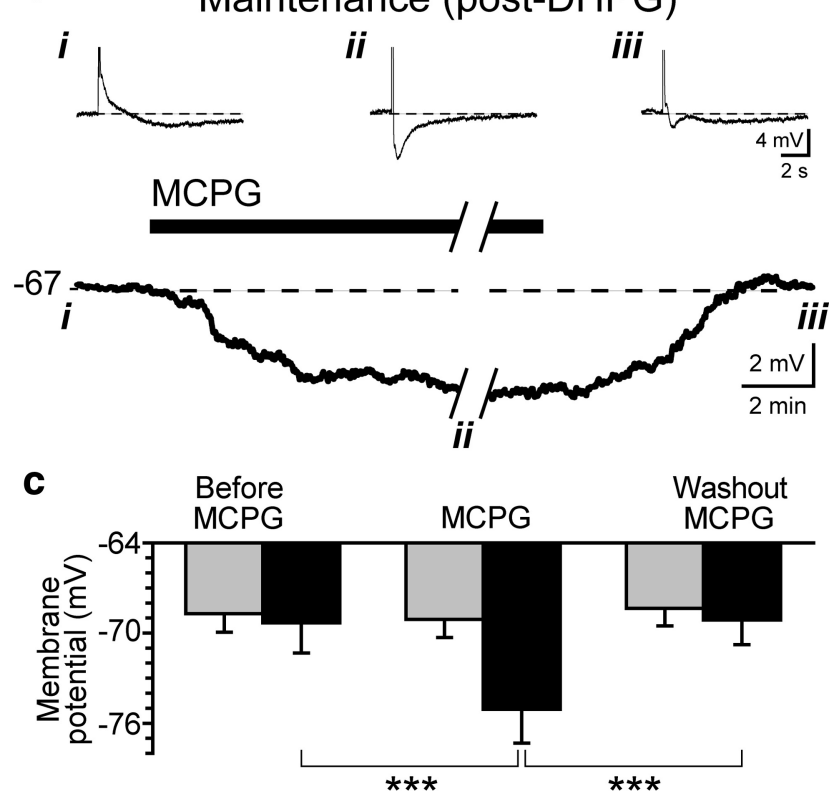

b

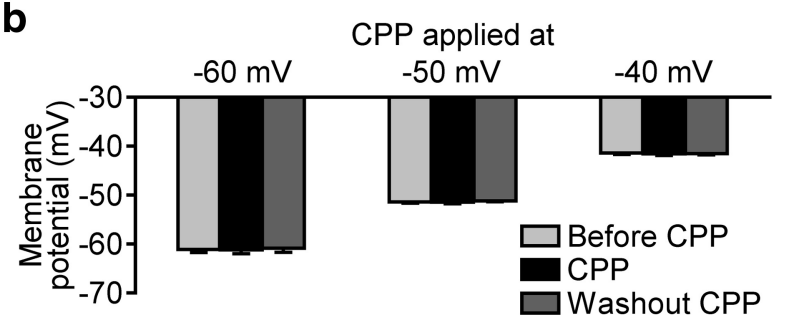

Figure 6. Elevated extracellular glutamate levels do not account for persistent AHP suppression. $A$, Application of iGluR blockers (CNQX and CPP) has no effect on the sAHP (upper traces) or on $V_{\mathrm{m}}$ (lower trace) in a CA3 pyramidal cell either before (Control, $\boldsymbol{A} \boldsymbol{a}$ ) or after (Post-DHPG, $\boldsymbol{A \boldsymbol { b }}$ ) 30 min treatment with DHPG. Baseline $V_{\mathrm{m},}$ indicated to left of the bottom trace, applies to all dashed lines. $\boldsymbol{B}$, On the other hand, MCPG, which also has no effect on AHP size (Control, upper traces) or $V_{\mathrm{m}}$ (lower trace) before DHPG treatment (Ba), caused a striking reversal of AHP suppression ( $\boldsymbol{B} \boldsymbol{b}$, Post-DHPG, upper trace, $\boldsymbol{B}$ bii) and hyperpolarized $V_{m}$ (lower trace) 35 min after DHPG washout. Baseline $V_{m}$, indicated to left of the bottom trace, applies to all dashed lines. In $\boldsymbol{A}$ and $\boldsymbol{B}$, bars above bottom records represent application of blockers, breaks are 4 min gaps during which AHPs under blockers were recorded, and $\boldsymbol{A i}$-Aiii and $\boldsymbol{B i}$-Biii indicate the AHPs shown as upper traces and recorded before, during, and after blocker application, respectively. Slow AHPs were elicited by $100 \mathrm{~ms}$ depolarizing pulses of $+2.0 \mathrm{nA}(\boldsymbol{A})$ and $+2.5 \mathrm{nA}(\boldsymbol{B})$. Summary data of the effects of $\mathrm{CNQX}$ and CPP ( $A c$; Control, $n=8$; Maintenance, $n=7)$ and of MCPG (BC; Control, $n=4$; Maintenance, $n=4)$ applications before DHPG (Control; gray bars) and post-DHPG (Maintenance; black bars) on pyramidal cell $V_{m}$ ( $n=4$ cells per group). Neither drug treatment had any effect before DHPG (Control). MCPG, but not CNQX plus CPP, caused significant hyperpolarization following 30 - 40 min treatment with DHPG ${ }^{* * *} p<0.001$; see Results; three-way ANOVA, followed by Student-Newman-Keuls post-tests). Applications of blockers were 5-15 min in duration. In these experiments, TTX was present throughout. Ca, Application of CPP (20 $\mu \mathrm{m}$; bar) to a CA3 pyramidal cell recorded at three different membrane potentials $\left(V_{\mathrm{m}}\right.$ indicated at the beginning of each record) $30-60$ min post-DHPG. $\boldsymbol{C} \boldsymbol{b}$, Summary data of $V_{\mathrm{m}}$ before (light gray bars), during (black bars), and after (dark gray bars) CPP in three cells set at the indicated membrane potentials.

the mGluR5 antagonist (Merlin, 2002). We tested the effects of LY 367385 and MPEP on DHPG-induced synchronized discharges in hippocampal slices isolated from $\mathrm{Fmrl}^{-1-}$ mice.

DHPG $(50 \mu \mathrm{M})$ induced prolonged epileptiform discharges in CA3 pyramidal cells of Fmr1 ${ }^{-1-}$ preparations that are similar to those observed in wild-type mice (Zhao et al., 2004) and per- sisted long after DHPG washout (Fig. 8Aa, $A b$, Post-DHPG). Each prolonged synchronized discharge was $4-6 \mathrm{~s}$ in duration (Fig. 8Aa, $A b, B$, Post-DHPG, black bars) and occurred rhythmically (Fig. $8 A a, A b$, Post-DHPG, insets). Occasional short $(<1 \mathrm{~s})$ synchronized discharges occurred between prolonged discharges (Fig. 8Aa, Post-DHPG, inset, $B$, Post-DHPG, white bars). LY 
A

a

\section{Control DHPG}

\section{LY}
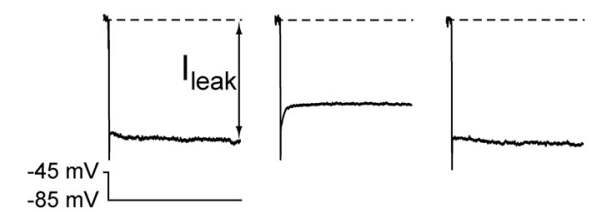

b

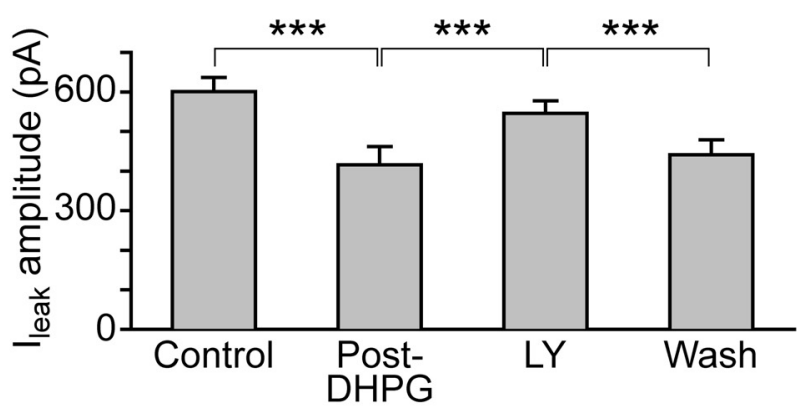

Wash

B

a

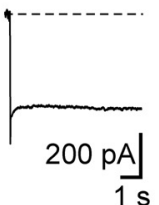

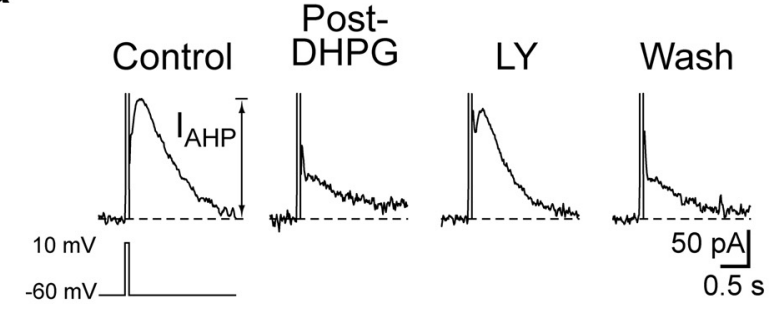

b

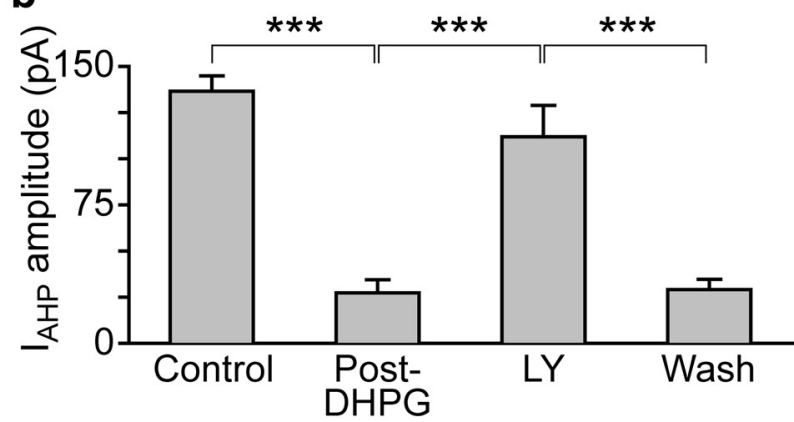

C
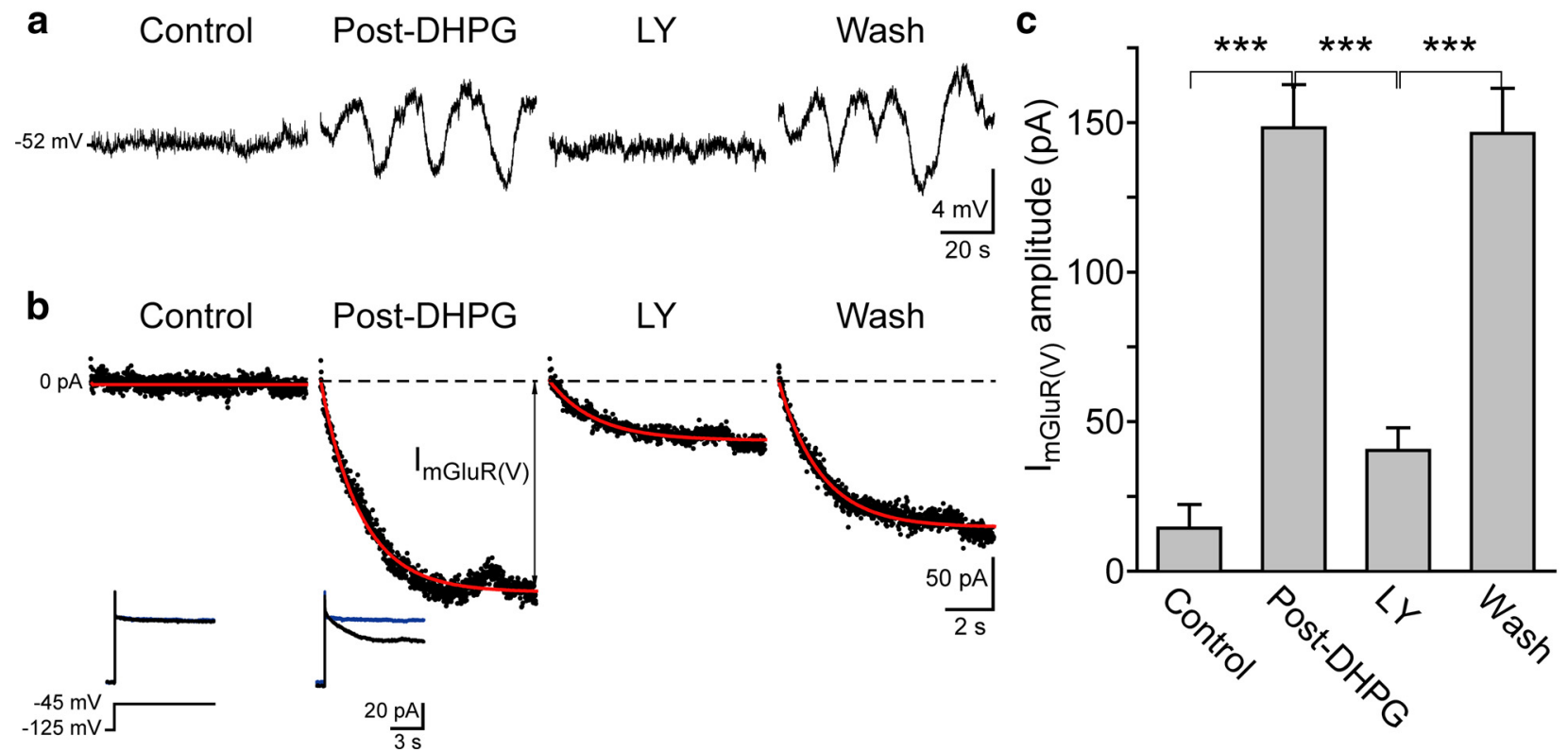

Figure 7. Effects of mGluR1 antagonist on post-DHPG $I_{\text {mGluR(V), }} I_{\text {leak }}$ and $I_{\text {AHP. }}$ Aa, Resting $I_{\text {leak }}$ (Control; top trace, double-headed arrow indicates current amplitude) assessed with a $40 \mathrm{mV}$ hyperpolarization (Control; bottom, voltage protocol) 60 min after DHPG washout is reduced (Post-DHPG). LY 367385 reversibly (Wash) returns I leak to pretreatment amplitude (LY). Dashed lines, Holding current $=1.1 \mathrm{nA}$. Ab, Summary data from nine cells showing sustained reduction in $I_{\text {leak }}$ (Control, Post-DHPG) and reversible block by LY 367385 (LY, Wash; see Results). Ba $I_{\text {AHP }}$ (Control; top trace, double-headed arrow indicates current amplitude) was elicited by a $50 \mathrm{~ms}$ depolarization of $70 \mathrm{mV}$ (Control; bottom, voltage protocol; unclamped action potentials are clipped) in the same cell shown in $A$. Following 35 min DHPG treatment, $I_{\text {AHP }}$ recorded 65 min after DHPG washout was reduced (Post-DHPG) and was reversibly rescued by LY 367385 (LY, 35 min; Wash, 60 min; see Results). Dashed lines, Holding current $=0.9 \mathrm{nA}$. B b , Summary data from eight cells showing persistent suppression (Control, Post-DHPG) and reversible rescue of the persistently suppressed $I_{\text {AHP }}$ using LY 367385 (LY, Wash; see Results; *** $p<0.001$, two-way ANOVA and Student-Newman-Keuls post-tests). Ca, Current-clamp recording of CA3 pyramidal cell in the presence of TTX (1 $\mu \mathrm{M}$ ). Control, Before 30 min treatment with DHPG; Post-DHPG, 30 min after DHPG washout; LY, 40 min in LY 367385; Wash, 45 min after LY 367385 washout. Cb, Voltage-clamp records of $I_{\text {mGluR(V) }}$ obtained by subtraction of two sweeps as shown in inset. Control, Before 30 min treatment with DHPG; Post-DHPG, 35 min after DHPG washout; LY, 45 min in LY 367385 ; Wash, 50 min after LY 367385 washout. Bottom trace in inset, Voltage step protocol. ImGluR(V) amplitude was measured at end of step (vertical double-arrowheaded line; (huang et al., 2000, 2001). Red lines are single exponential fits of the current traces for amplitude measurements. Cc, Summary $I_{\text {mGluR(V) }}$ measurements obtained as in $\boldsymbol{C b}$ for six cells after exposure to DHPG for 30 min (*** $p<0.001$, two-way ANOVA and Student-Newman-Keuls post-tests).

$367385(50 \mu \mathrm{M})$ prevented the occurrence of prolonged discharges, whereas short discharges of $<1 \mathrm{~s}$ were not affected (Fig. 8 Aaii, $B, \mathrm{LY})$. In the presence of MPEP $(50 \mu \mathrm{M})$, the duration of prolonged epileptiform discharges was significantly reduced from $5328 \pm 657 \mathrm{~ms}(n=8)$ in control to $3114 \pm 574 \mathrm{~ms}(p<$ $0.01 ; n=4$; Fig. $8 A b i i, B$, MPEP).

Data from eight cells in six $\mathrm{Fmrl}^{-1-}$ slices are summarized in Figure $8 B$, showing a significantly larger effect of LY 367385 in 
A
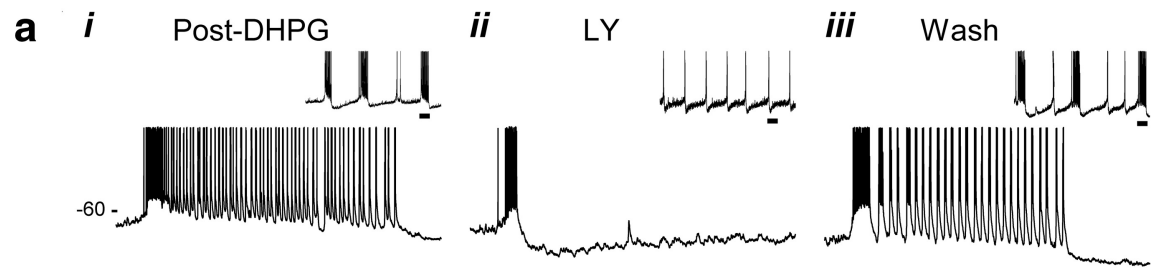

b $i$

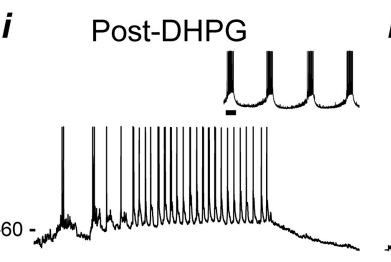

ii MPEP

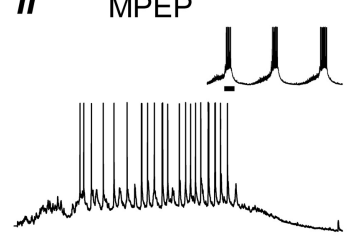

iii

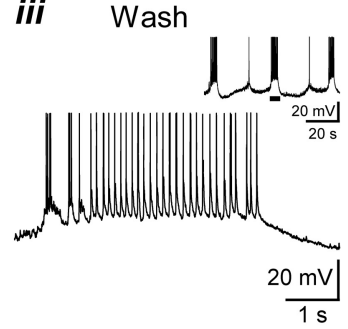

B

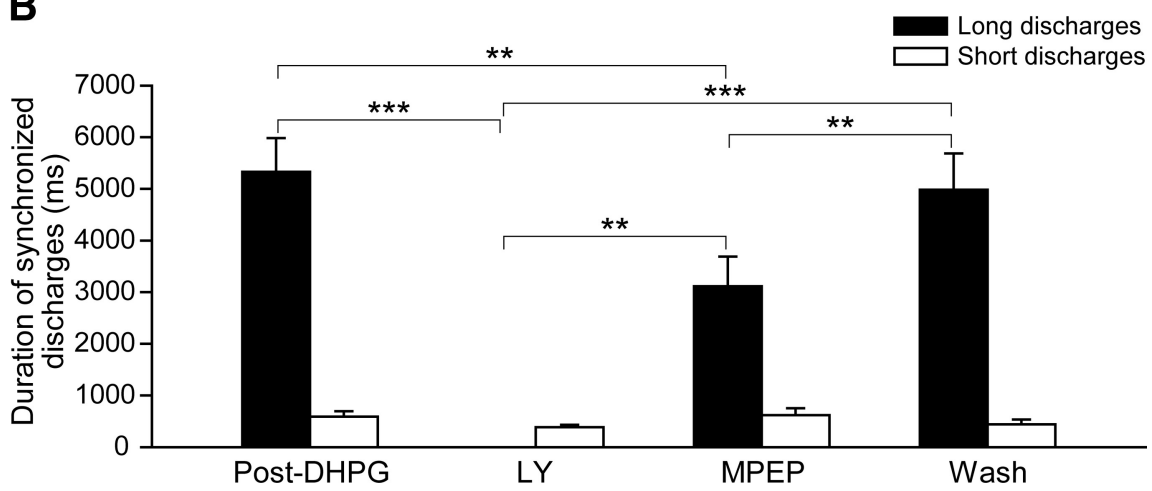

Figure 8. LY 367385 is more effective than MPEP in suppressing group I mGluR-induced prolonged epileptiform discharges in $\mathrm{Fmr1}^{-1-}$ hippocampal slices. $\boldsymbol{A}$, Prolonged epileptiform discharges induced by DHPG $(50 \mu \mathrm{M})$ in a CA3 pyramidal cell from a $\mathrm{Fmr}^{-1-}$ mouse persisted $30 \mathrm{~min}$ (Aai) and $90 \mathrm{~min}$ (Abi) after DHPG washout (Post-DHPG). Inset, Rhythmic synchronized discharges recorded in the indicated conditions. The representative single discharges shown on faster time scales are marked by bars in the insets. Aaii, Synchronized discharges recorded at 25 min of LY 367385 (LY; $50 \mu \mathrm{M})$ application. Aaiii, 40 min after LY 367385 washout (Wash). Abi, Prolonged epileptiform discharges maintained $90 \mathrm{~min}$ after DHPG washout (Post-DHPG). Abii, Discharges recorded at $45 \mathrm{~min}$ in the presence of MPEP $(50 \mu \mathrm{M})$. Abiii, 40 min after MPEP washout (Wash). $\boldsymbol{B}$, Summary data from eight cells recorded in slices from six Fmr $1^{-1-}$ animals. Both long (black bars) and short (white bars) discharges persisted after DHPG washout (Post-DHPG). Persistent long discharges (Post-DHPG, $5328 \pm 657 \mathrm{~ms} ; n=8$ ), were blocked by LY 367385 (LY, 50 $\mu \mathrm{m} ; n=4$ ) and shortened by MPEP to $3114 \pm 574 \mathrm{~ms}$ (MPEP, $50 \mu \mathrm{m} ; n=4$ ), in a reversible manner (Wash, $4981 \pm 704 \mathrm{~ms}$ ). In contrast, short discharges (Post-DHPG, $588 \pm 105 \mathrm{~ms} ; n=7$ ) were not significantly affected by either antagonist (LY, $382 \pm 51$ $\mathrm{ms} ; n=4 ;$ MPEP, $617 \pm 134 \mathrm{~ms} ; n=3$ ), or by their washout (Wash, $439 \pm 94 \mathrm{~ms} ; n=7$ ). Comparisons were made using one-way ANOVA and Student-Newman-Keuls post-tests $\left({ }^{* *} p<0.01 ;{ }^{* * *} p<0.001\right)$.

suppressing prolonged epileptiform discharges in $\mathrm{Fmrl}^{-1-}$ hippocampal slices than that of MPEP $(p=0.006)$. Thus, the relative sensitivity of persistent cellular responses induced by DHPG to group I mGluR antagonists is retained at the population level. Previously, we showed that MPEP shortens the synaptically activated prolonged epileptiform discharges in $\mathrm{Fmrl}^{-1-}$ preparations (Chuang et al., 2005). Synaptically activated prolonged discharges are sustained by a smaller number of active mGluRs (restricted to postsynaptic sites) compared with agonistinduced events, which involve the entire surface receptor population. Thus, maintenance of synaptically induced events may require synergistic action of mGluR 1 and mGluR5, and is more susceptible to blockade of mGluR5 (Chuang et al., 2005).

\section{Discussion}

This study shows that persistent group I mGluR-induced epileptiform activity and associated cellular responses can be reversibly antagonized by application of group I mGluR blockers. The data further indicate that persistent group I mGluR responses are not maintained by residual action of the applied agonist or by endogenous glutamate. Instead, we suggest the possibility that ligand-independent receptor activity plays a role in the maintenance of group I mGluR-mediated plasticity.

\section{How are group I mGluRs \\ persistently activated?}

Persistent group I mGluR activity can arise from three possible causes. First, DHPG washout may be incomplete. Second, receptor activity can be maintained by enhanced endogenous glutamate release. Third, persistent receptor activity may arise from a constitutively active state of the receptor in the absence of agonist stimulation.

Slow washout of DHPG is an unlikely explanation for persistent AHP suppression because of the differential involvement of group I mGluR subtypes in the direct response to DHPG and in the maintenance of long-lasting responses. Our data indicate that activation of mGluR1 plays a predominant role in maintaining persistent AHP suppression (Fig. 3C), whereas DHPG activates both mGluR1 and mGluR5 and activation of either one of these receptor types alone can suppress the AHP (Young et al., 2008). Furthermore, if it is supposed that persistent group I mGluR activity was maintained by the continued presence of DHPG after washout, then the efficacy of MCPG in blocking the maintained cellular responses should be similar to the MCPG block of cellular responses elicited directly by DHPG. Figure 4 shows that this is not the case. The MCPG dose-response relationship for the rescue of DHPGsuppressed AHP during DHPG application is significantly different compared with that obtained for the persistent responses maintained after DHPG washout (Fig. 4). The doseresponse curve for the persistent response is consistent with a predominant action of the antagonist on a single receptor population (mGluR1, as discussed above) whereas the action of the antagonist on direct DHPG-activated response is more consistent with the presence of two receptor populations.

Another explanation of the persistent group I mGluRmediated effect is increased endogenous glutamate stimulation. Experiments using TTX or low $\mathrm{Ca}^{2+}$-high $\mathrm{Mn}^{2+}$ perfusion suggest that persistent receptor activity is not dependent on action potential-dependent or spontaneous synaptic release of glutamate (Fig. 5).

To address the possibility that high glutamate levels, resulting from nonsynaptic release from neurons or glia (Fellin et al., 2004; Pirttimaki et al., 2011), may maintain persistent group I mGluR activity, we examined cellular responses to iGluRs. Presumably, ambient glutamate sufficient to activate 
group I mGluRs would also activate iGluRs, thereby producing cell depolarization. Figure $6 \mathrm{~A}$ shows that pulse applications of CNQX and CPP, blockers of AMPA and NMDA receptors, respectively, did not elicit any noticeable change in membrane potential either before or after DHPG treatment. NMDA receptor responses, which might have been unavailable at the membrane holding potential, were tested by depolarizing the cell before application of CPP (Fig. 6C). In contrast, MCPG applications post-DHPG elicited significant membrane hyperpolarization and reversed AHP suppression (Fig. 6B), indicating persistent group I mGluR activation. Group I mGluR stimulation depolarizes CA3 cells by increasing $\mathrm{R}_{\text {in }}$ (Figs. $2 D, 7 A$ ) through suppression of leak $\mathrm{K}^{+}$conductances (Chuang et al., 2001) and activation of $I_{\mathrm{mGluR}(\mathrm{V})}$ (Fig. 7C) (Chuang et al., 2000). MCPG-induced hyperpolarization may be mediated by reversing suppressed leak $\mathrm{K}^{+}$conductances (Bianchi et al., 1999; Chuang et al., 2001) and by suppressing $I_{\mathrm{m}^{-}}$ GluR(V). Previous data showed that MCPG at a concentration of 250 $\mu \mathrm{M}$ did not affect $I_{\mathrm{mGluR}(\mathrm{V})}$ amplitude post-DHPG (Bianchi et al., 2009). Since MCPG at higher dosage is more efficacious in relieving suppressed AHP post-DHPG (Fig. 4), it is possible that MCPG applied at a higher dose $(500 \mu \mathrm{M})$, as used in these experiments (Fig. $7 B$ ), also suppressed $I_{\mathrm{mGluR}(\mathrm{V})}$, contributing to the observed hyperpolarization.

An alternative hypothesis for persistent group I mGluR responses is that they are sustained by constitutive receptor activity. Constitutive activity on the part of G-proteincoupled receptors (GPCRs), including group I mGluRs, is now widely appreciated in expression systems, where endogenous agonist is absent (Costa and Herz, 1989; Milligan, 2003; Gilchrist, 2007; Niswender and Conn, 2010). Proof of GPCR constitutive activity in native tissue-where endogenous agonist is present-is more difficult, but has been reported for $5 \mathrm{HT}_{1 \mathrm{a}}$ receptors in rat hippocampus (Martel et al., 2007). Constitutive activity of group I mGluRs can result from receptor conformation changes due to allosteric modulation via mutation of allosteric binding sites (Malherbe et al., 2003a,b; Yanagawa et al., 2009) or through binding of intracellular ligands, such as the protein Homerla, to the C-terminal domain of the receptor (Brakeman et al., 1997; Ango et al., 2001; Fagni et al., 2004; Ritter and Hall, 2009).

Thus, constitutive activity in GPCRs can arise from an active state of the ligand binding domain or the transmembrane heptahelical domain (Parmentier et al., 2002; Rondard et al., 2011). In expression systems, constitutive activity of mGluR 1 a is conferred by the active state of the transmembrane heptahelical domain (Malherbe et al., 2003a,b; Yanagawa et al., 2009). MCPG, which is a competitive antagonist acting on the binding domain, was ineffective against this form of constitutive receptor activity (Ango et al., 2001). However, group I mGluR constitutive activity could also arise from an active ligand binding domain (Parmentier et al., 2002; Rondard et al., 2011). Indeed, $x$-ray crystallographic studies show that the ligand binding domain exists spontaneously in both open (inactive) and closed (active) states (Kunishima et al., 2000). It is possible that constitutive mGluR activity maintaining mGluRmediated plasticity in CA3 neurons arises from a shift of equilibrium of the binding domain toward the active state. MCPG stabilizes the inactive state (Tsuchiya et al., 2002) and may thus be effective against this form of constitutive mGluR activity. Our results do not provide any indication of whether this mechanism is involved in maintaining mGluR activity, but the effectiveness of MCPG block suggests that, if constitu- tive activity were induced by transient DHPG stimulation, it is most likely conferred by a conformation change of the ligand binding domain (but, see Kelly et al., 2009).

It is of interest to note that studies on group I mGluRmediated plasticity responses (epileptogenesis, Merlin and Wong, 1997; LTD, Huber et al., 2000; signal transduction, Hou and Klann, 2004) have used DHPG as the agonist. Parallel studies on activation of group I mGluRs by glutamate have not been carried out. In some cases, glutamate exposure in hippocampal slices was shown to cause a suppression of overall protein synthesis (Orrego and Lipmann, 1967; Marin et al., 1997), instead of an enhancement, as observed with DHPG (Osterweil et al., 2010). Thus, specific conditions for glutamate activation of group I mGluRs remains unclear. Glutamate involvement in group I mGluR-mediated plasticity is shown by synaptic stimulation studies. DHPG-induced LTD mimics LTD activated by specifically patterned afferent stimulation (Huber et al., 2000). DHPGinduced prolonged epileptiform discharges are also induced synaptically in Fmr1 ${ }^{-1-}$ mice (Chuang et al., 2005). Such stimulation also elicits $I_{\text {mGluR(V) }}$ (Bianchi et al., 2009). Similar to DHPG-induced responses, synaptically induced discharges in $F m r 1^{-1-}$ preparations are suppressed by group I mGluR blockers (Chuang et al., 2005).

\section{Involvement of mGluR1 vs mGluR5}

Previous work has shown that mGluR5 is the predominant receptor subtype responsible for the induction of persistent AHP suppression (Young et al., 2008). In contrast, present results indicate that mGluR1 is the predominant receptor maintaining persistent AHP suppression (Fig. 3). Other studies also show that mGluR1 has a major role in the maintenance of prolonged epileptiform discharges in the hippocampus, compared with mGluR5, which mainly mediates the induction of prolonged epileptiform discharges (Merlin, 2002; see also Fig. 8). Our results are from the CA3 region of the hippocampus and differ from what has been recently reported in the CA1 region, where mGluR 5 activity has been proposed to maintain LTD (Huang and Hsu, 2006; Ronesi et al., 2012). These results indicate possible different roles of group I mGluR subtypes in the CA1 versus CA3 regions. Also pointing in this direction is that the key ionic current, $I_{\mathrm{mGluR}(\mathrm{V})}$, elicited by group I mGluR stimulation and sustaining prolonged discharges (Bianchi et al., 2009) is only activated in CA3 and not CA1 pyramidal cells (Chuang et al., 2002).

In addition to persistent mGluR1 activation, signaling can also be modified to sustain group I mGluR-dependent plasticity. In fragile X syndrome preparations, increased sensitivity of protein synthesis to background mGluR5 signaling was proposed to be the cause of the observed persistent receptor-dependent protein synthesis (Osterweil et al., 2010).

In summary, this study shows that group I mGluRmediated plasticity in the CA3 region of hippocampus is mediated by persistent receptor activation. Whereas the exact mechanism eliciting the persistent activation is still unclear, data indicate that it does not involve activation by known applied (DHPG) or endogenous (glutamate) ligands. Induction of constitutively active mGluR1 appears likely, although it remains possible that the induction process caused the tonic release of an unidentified endogenous agonist that elicited sustained, preferential activation of mGluR1 over that of mGluR5 in the CA3 region. 


\section{References}

Ango F, Prézeau L, Muller T, Tu JC, Xiao B, Worley PF, Pin JP, Bockaert J, Fagni L (2001) Agonist-independent activation of metabotropic glutamate receptors by the intracellular protein Homer. Nature 411:962-965. CrossRef Medline

Bandrowski AE, Huguenard JR, Prince DA (2003) Baseline glutamate levels affect group I and II mGluRs in layer V pyramidal neurons of rat sensorimotor cortex. J Neurophysiol 89:1308-1316. Medline

Bear MF, Huber KM, Warren ST (2004) The mGluR theory of fragile X mental retardation. Trends Neurosci 27:370-377. CrossRef Medline

Bianchi R, Wong RKS (1995) Excitatory synaptic potentials dependent on metabotropic glutamate receptor activation in guinea-pig hippocampal pyramidal cells. J Physiol 487:663-676. Medline

Bianchi R, Young SR, Wong RK (1999) Group I mGluR activation causes voltage-dependent and -independent $\mathrm{Ca}^{2+}$ rises in hippocampal pyramidal cells. J Neurophysiol 81:2903-2913. Medline

Bianchi R, Chuang SC, Zhao W, Young SR, Wong RK (2009) Cellular plasticity for group I mGluR-mediated epileptogenesis. J Neurosci 29:3497-3507. CrossRef Medline

Brakeman PR, Lanahan AA, O’Brien R, Roche K, Barnes CA, Huganir RL, Worley PF (1997) Homer: a protein that selectively binds metabotropic glutamate receptors. Nature 386:284-288. CrossRef Medline

Chuang SC, Bianchi R, Wong RK (2000) Group I mGluR activation turns on a voltage-gated inward current in hippocampal pyramidal cells. J Neurophysiol 83:2844-2853. Medline

Chuang SC, Bianchi R, Kim D, Shin HS, Wong RK (2001) Group I metabotropic glutamate receptors elicit epileptiform discharges in the hippocampus through PLC $\beta 1$ signaling. J Neurosci 21:6387-6394. Medline

Chuang SC, Zhao W, Young SR, Conquet F, Bianchi R, Wong RK (2002) Activation of group I mGluRs elicits different responses in murine CA1 and CA3 pyramidal cells. J Physiol 541:113-121. CrossRef Medline

Chuang SC, Zhao W, Bauchwitz R, Yan Q, Bianchi R, Wong RK (2005) Prolonged epileptiform discharges induced by altered group I metabotropic glutamate receptor-mediated synaptic responses in hippocampal slices of a fragile X mouse model. J Neurosci 25:8048-8055. CrossRef Medline

Costa T, Herz A (1989) Antagonists with negative intrinsic activity at delta opioid receptors coupled to GTP-binding proteins. Proc Natl Acad Sci U S A 86:7321-7325. CrossRef Medline

D'Ambrosio R, Hakimian S, Stewart T, Verley DR, Fender JS, Eastman CL, Sheerin AH, Gupta P, Diaz-Arrastia R, Ojemann J, Miller JW (2009) Functional definition of seizure provides new insight into post-traumatic epileptogenesis. Brain 132:2805-2821. CrossRef Medline

Dölen G, Osterweil E, Rao BS, Smith GB, Auerbach BD, Chattarji S, Bear MF (2007) Correction of fragile X syndrome in mice. Neuron 56:955-962. CrossRef Medline

Fagni L, Ango F, Perroy J, Bockaert J (2004) Identification and functional roles of metabotropic glutamate receptor-interacting proteins. Semin Cell Dev Biol 15:289-298. CrossRef Medline

Fellin T, Pascual O, Gobbo S, Pozzan T, Haydon PG, Carmignoto G (2004) Neuronal synchrony mediated by astrocytic glutamate through activation of extrasynaptic NMDA receptors. Neuron 43:729-743. CrossRef Medline

Gilchrist A (2007) Modulating G-protein-coupled receptors: from traditional pharmacology to allosterics. Trends Pharmacol Sci 28:431-437. CrossRef Medline

Hou L, Klann E (2004) Activation of the phosphoinositide 3-kinase-Aktmammalian target of rapamycin signaling pathway is required for metabotropic glutamate receptor-dependent long-term depression. J Neurosci 24:6352-6361. CrossRef Medline

Huang CC, Hsu KS (2006) Sustained activation of metabotropic glutamate receptor 5 and protein tyrosine phosphatases mediate the expression of (S)-3,5-dihydroxyphenylglycine-induced long-term depression in the hippocampal CA1 region. J Neurochem 96:179-194. CrossRef Medline

Huber KM, Kayser MS, Bear MF (2000) Role for rapid dendritic protein synthesis in hippocampal mGluR-dependent long-term depression. Science 288:1254-1257. CrossRef Medline

Johnson JW, Ascher P (1990) Voltage-dependent block by intracellular $\mathrm{Mg} 2+$ of N-methyl-D-aspartate-activated channels. Biophys J 57:10851090. CrossRef Medline

Kelly L, Farrant M, Cull-Candy SG (2009) Synaptic mGluR activation drives plasticity of calcium-permeable AMPA receptors. Nat Neurosci 12:593601. CrossRef Medline

Kunishima N, Shimada Y, Tsuji Y, Sato T, Yamamoto M, Kumasaka T, Nakanishi S, Jingami H, Morikawa K (2000) Structural basis of glutamate recognition by a dimeric metabotropic glutamate receptor. Nature 407 : 971-977. CrossRef Medline

Lalo U, Pankratov Y, Kirchhoff F, North RA, Verkhratsky A (2006) NMDA receptors mediate neuron-to-glia signaling in mouse cortical astrocytes. J Neurosci 26:2673-2683. CrossRef Medline

Malherbe P, Kratochwil N, Knoflach F, Zenner MT, Kew JN, Kratzeisen C, Maerki HP, Adam G, Mutel V (2003a) Mutational analysis and molecular modeling of the allosteric binding site of a novel, selective, noncompetitive antagonist of the metabotropic glutamate 1 receptor. J Biol Chem 278:8340 - 8347. CrossRef Medline

Malherbe P, Kratochwil N, Zenner MT, Piussi J, Diener C, Kratzeisen C, Fischer C, Porter RH (2003b) Mutational analysis and molecular modeling of the binding pocket of the metabotropic glutamate 5 receptor negative modulator 2-methyl-6-(phenylethynyl)-pyridine. Mol Pharmacol 64:823-832. CrossRef Medline

Marin P, Nastiuk KL, Daniel N, Girault JA, Czernik AJ, Glowinski J, Nairn AC, Prémont J (1997) Glutamate-dependent phosphorylation of elongation factor-2 and inhibition of protein synthesis in neurons. J Neurosci 17:3445-3454. Medline

Martel JC, Ormière AM, Leduc N, Assié MB, Cussac D, Newman-Tancredi A (2007) Native rat hippocampal 5- $\mathrm{HT}_{1 \mathrm{~A}}$ receptors show constitutive activity. Mol Pharmacol 71:638-643. CrossRef Medline

Matveeva EA, Davis VA, Whiteheart SW, Vanaman TC, Gerhardt GA, Slevin JT (2012) Kindling-induced asymmetric accumulation of hippocampal 7S SNARE complexes correlates with enhanced glutamate release. Epilepsia 53:157-167. CrossRef Medline

McNamara JO, Huang YZ, Leonard AS (2006) Molecular signaling mechanisms underlying epileptogenesis. Sci STKE 356:re12. CrossRef Medline

Merlin LR (2002) Differential roles for mGluR1 and mGluR5 in the persistent prolongation of epileptiform bursts. J Neurophysiol 87:621-625. Medline

Merlin LR, Wong RK (1997) Role of group I metabotropic glutamate receptors in the patterning of epileptiform activities in vitro. J Neurophysiol 78:539-544. Medline

Milligan G (2003) Constitutive activity and inverse agonists of G proteincoupled receptors: a current perspective. Mol Pharmacol 64:1271-1276. CrossRef Medline

Motulsky HJ, Ransnas LA (1987) Fitting curves to data using nonlinear regression: a practical and nonmathematical review. FASEB J 1:365-374. Medline

Musumeci SA, Hagerman RJ, Ferri R, Bosco P, Dalla Bernardina B, Tassinari CA, De Sarro GB, Elia M (1999) Epilepsy and EEG findings in males with fragile X syndrome. Epilepsia 40:1092-1099. CrossRef Medline

Niswender CM, Conn PJ (2010) Metabotropic glutamate receptors: physiology, pharmacology, and disease. Annu Rev Pharmacol Toxicol 50:295322. CrossRef Medline

Orrego F, Lipmann F (1967) Protein synthesis in brain slices. J Biol Chem 242:665-671. Medline

Osterweil EK, Krueger DD, Reinhold K, Bear MF (2010) Hypersensitivity to mGluR5 and ERK1/2 leads to excessive protein synthesis in the hippocampus of a mouse model of fragile X syndrome. J Neurosci 30:1561615627. CrossRef Medline

Palmer MJ, Irving AJ, Seabrook GR, Jane DE, Collingridge GL (1997) The group I mGlu receptor agonist DHPG induces a novel form of LTD in the CA1 region of the hippocampus. Neuropharmacology 36:1517-1532. CrossRef Medline

Pan YZ, Karr L, Rutecki P (2010) Ictal activity induced by group I metabotropic glutamate receptor activation and loss of afterhyperpolarizations. Neuropharmacology 59:86-92. CrossRef Medline

Parmentier ML, Prézeau L, Bockaert J, Pin JP (2002) A model for the functioning of family 3 GPCRs. Trends Pharmacol Sci 23:268-274. CrossRef Medline

Pirttimaki TM, Hall SD, Parri HR (2011) Sustained neuronal activity generated by glial plasticity. J Neurosci 31:7637-7647. CrossRef Medline

Ritter SL, Hall RA (2009) Fine-tuning of GPCR activity by receptorinteracting proteins. Nat Rev Mol Cell Biol 10:819-830. CrossRef Medline

Rondard P, Goudet C, Kniazeff J, Pin JP, Prézeau L (2011) The complexity 
of their activation mechanism opens new possibilities for the modulation of mGlu and $\mathrm{GABA}_{\mathrm{B}}$ class $\mathrm{C} G$ protein-coupled receptors. Neuropharmacology 60:82-92. CrossRef Medline

Ronesi JA, Collins KA, Hays SA, Tsai NP, Guo W, Birnbaum SG, Hu JH, Worley PF, Gibson JR, Huber KM (2012) Disrupted Homer scaffolds mediate abnormal mGluR5 function in a mouse model of fragile X syndrome. Nat Neurosci 15:431-440, S1. CrossRef Medline

Sabaratnam M, Vroegop PG, Gangadharan SK (2001) Epilepsy and EEG findings in 18 males with fragile X syndrome. Seizure 10:60-63. CrossRef Medline

Taylor GW, Merlin LR, Wong RK (1995) Synchronized oscillations in hippocampal CA3 neurons induced by metabotropic glutamate receptor activation. J Neurosci 15:8039-8052. Medline

Tsuchiya D, Kunishima N, Kamiya N, Jingami H, Morikawa K (2002) Structural views of the ligand-binding cores of a metabotropic glutamate receptor complexed with an antagonist and both glutamate and $\mathrm{Gd}^{3+}$. Proc Natl Acad Sci U S A 99:2660-2665. CrossRef Medline

Wong RK, Bianchi R, Taylor GW, Merlin LR (1999) Role of metabotropic glutamate receptors in epilepsy. Adv Neurol 79:685-698. Medline
Wong RK, Chuang SC, Bianchi R (2002) Metabotropic glutamate receptors and epileptogenesis. Epilepsy Curr 2:81-85. CrossRef Medline

Yanagawa M, Yamashita T, Shichida Y (2009) Activation switch in the transmembrane domain of metabotropic glutamate receptor. Mol Pharmacol 76:201-207. CrossRef Medline

Young SR, Chuang SC, Wong RK (2004) Modulation of afterpotentials and firing pattern in guinea pig CA3 neurones by group I metabotropic glutamate receptors. J Physiol 554:371-385. CrossRef Medline

Young SR, Bianchi R, Wong RK (2008) Signaling mechanisms underlying group I mGluR-induced persistent AHP suppression in CA3 hippocampal neurons. J Neurophysiol 99:1105-1118. CrossRef Medline

Zhao W, Bianchi R, Wang M, Wong RK (2004) Extracellular signal-regulated kinase $1 / 2$ is required for the induction of group I metabotropic glutamate receptor-mediated epileptiform discharges. J Neurosci 24:76-84. CrossRef Medline

Zhao W, Chuang SC, Bianchi R, Wong RK (2011) Dual regulation of fragile $\mathrm{X}$ mental retardation protein by group I metabotropic glutamate receptors controls translation-dependent epileptogenesis in the hippocampus. J Neurosci 31:725-734. CrossRef Medline 